\title{
MALEZAS NO HALÓFITAS DEL EXTREMO SUR DEL PERÚ
}

Rosario Zegarra Z. ${ }^{1}$

\author{
R E S U M E N
}

Se describen 52 especies pertenecientes a 24 familias de plantas, las cuales se colectaron en parques, jardines de casas particulares, huertos, chacras, Ciudad Universitaria y Centros Experimetales de la Facultad de Ciencias Agricolas, de la Universidad Nacional uJorge Basadre Grohmann».

Las familias con mayor número de especies son las Gramineas con 8, Compuestas con 7, Euphorbiaceas con 5 y Leguminosas con 4.

\section{A B S T R A C T}

Fifty two species are described related to twenty four genuses, which were collected from parks, particular home gardens, small orchards, farms, university campus and experimental centers of the Agriculture Faculty of Universidad Nacional Jorge Basadre Grohmann.

The genuses with major number of species are Gramineae with 8 , compounds with 7 , Euphorbiaceae with 5 , and Legumes with 4.

\section{I.INTRODUCCIÓN}

Hay especies invasoras que pueden convertirse en malezas. Cuando empleamos este término, nos referimos a una planta que crece espontáneamente entre las cultivadas, comportándose como un fuerte competidor de una especie de valor económico. Son especies rústicas que se adaptan fácilmente, lo cual favorece la dominancia. Los animales no las consumen, esto favorece su masiva multiplicación. Aunque hay malezas que no son dañinas, porque son beneficiosas para la agricultura por presentar en sus raíces nódulos nitrificantes, o pueden ser utilizadas como abono verde o son palatables.

Otras son hospedantes de plagas y agentes patógenos como Sonchus asper y Sonchus oleraceus que son hospederos de áfidos como Ureolucon sonchi Geofr e Hiperomizus lactucae L., o Aphis craccivora Koch sobre Trifolium repens,

1. Doctora en Biología.

\section{o en Nicotiana paniculata se halló Macrosiphum euphorbiae Thomas.}

En el mundo entero existen aproximadamente 300,000 especies de angiospermas (plantas con flores). Este grupo incluye casi todas las plantas consideradas como dañinas o invasoras (cerca de 30,000).

El presente estudio incluye familias de plantas invasoras, principalmente de cultivos anuales y perennes. Se estudian las características morfológicas de órganos vegetativos, flor y fruto, de las especies más frecuentes que se encontraron en campos cultivados de suelos no halófitos.

\section{MATERIALES Y MÉTODOS}

El material botánico fue colectado por la autora. Se ha empleado el método de observación directa.

Las ilustraciones que acompañan al texto, fueron ejecutadas con material fresco y algunas con ejemplares de herbario. 
III.CARACTERÍSTICAS PRACTICAS PARA EL RECONOCIMIENTO DE ALGUNAS FAMILIAS IMPORTANTES DE PLANTAS INVASORAS EN TACNA

\subsection{DIVISIÓN PTERIDOPHYTA}

Sin flores verdaderas, se reproducen por medio de esporas y/o vegetativamente.

\subsubsection{FAMILIA EQUISETACEAE (Helechos)}

Tallo articulado, estriado y hueco; rizoma subterráneo; hojas pequeñas; estróbilos terminales en los ápices de ramas fértiles.

Ejemplo: Equisetum

\subsection{DIVISIÓN SPERMATOPHYTA}

Con flores verdaderas, se reproducen por medio de semillas y/o vegetativamente.

\section{A. SUBDIVISIÓN ANGIOSPERMAE}

a) CLASE MONOCOTYLEDONAE

\subsubsection{FAMILIA GRAMINEAE (POÁCEAS)}

Plantas herbáceas o leñosas; cañas plurinodes huecas o macizas; hojas dísticas; lámina foliar lanceolada o lineal; lígula membranácea o pilosa normalmente presente; a veces auricula; vaina generalmente abierta. Inflorescencia en panoja o espiga; espiguillas disticas.

Géneros: Bromus, Echinochloa, Penniscetum, Poa, Setaria, Sorghum, Sporobolus.

\subsubsection{FAMILIA LILIACEAE}

Flores vistosas; perigonio actinomorfo, petaloide; androceo con 6 estambres; ovario súpero tricarpelar.

Género: Nothoscordum

\section{b) CLASE DICOTYLEDONEAE}

\subsubsection{FAMILIA POLYGONACEAE}

Nudos del tallo gruesos o protuberantes; con ócrea; presencia de cerocina; savia ácida y penetrante.

Géneros: Polygonum, Rumex.

\subsubsection{FAMILIA URTICACEAE}

Con pelos urticantes; flores verdosas, pequeñas, unisexuales generalmente.

Fruto : Aquenio
Género

\subsubsection{FAMILIA CHENOPODIACEAE}

Hierbas o arbustos halófilos; tallo estriado. Hojas simples, alternas u opuestas, lineales, lanceoladas, hastadas. Monoicas o dioicas. Flores hermafroditas o unisexuales. Inflorescencia cimosa axilar o terminal. Fruto utrículo o aquenio con pericarpio membranoso.

Género: Chenopodium

\subsubsection{FAMILIA AMARANTHACEAE}

Arbustos o hierbas no fibrosas; hojas simples alternas u opuestas; inflorescencia glomerular; flores hermafroditas o polígamas, pequeñas de color verde; sépalos escariosos, con brácteas accesorias.

Fruto : Utrículo o pixidio uniseminado.

Géneros : Alternanthera, Amaranthus.

\subsubsection{FAMILIA RANUNCULACEAE}

Plantas arbustivas o herbáceas erguidas o volubles. Hojas simples o compuestas. Flores hermafroditas, actinomorfas o zigomorfas, solitarias o en inflorescencias diversas. Fruto aquenio, baya o folículo.

Género: Clematis

\subsubsection{FAMILIA PAPAVERACEAE}

Plantas laticiferas. Hojas simples alternas, muchas veces espinosas. Dos sépalos, pétalos corrugados. Ovario unilocular, con muchos óvulos.

Género: Argemone

\subsubsection{FAMILIA CRUCIFERAE (Brassicaceae)}

Flores tetrámeras. Estambres tetradínamos (4 comprimidos hacia dentro y 2 curvados hacia fuera).

Fruto : Silicua, dividido por el septo o replo en dos lóculos.

Género : Coronopus

\subsubsection{FAMILIA FUMARIACEAE}

Hojas pinnatisectas. Flores zigomorfas. Fruto drupáceo seco o unidehiscente en forma de 
pequeña silicua globosa con una sola semilla.

Género : Fumaria

\subsubsection{FAMILIA LEGUMINOSAE (FABÁCEAS)}

\section{- Subfamilia Papilionoideas}

Hojas pinnadas o trifoliadas. Flores zigomorfas, papilionáceas. Estambres generalmente diadelfos.

Fruto : Legumbre o vaina, drupa o sámara.

Géneros : Crotalaria, Medicago, Trifolium, Vicia.

\subsubsection{FAMILIA OXALIDACEAE}

Hojas trifoliadas. Especies con ácido oxálico. Flores agrupadas en cima.

Fruto : Cápsula.

Género: Oxalis.

\subsubsection{FAMILIA ZYGOPHYLLACEAE}

Plantas rastreras. Hojas compuestas, estipuladas.

Fruto : Capsular, con 4-5 lóculos.

Género : Tribulus

\subsubsection{FAMILIA EUPHORBIACEAE}

Especies laticíferas. En el género Euphorbia la inflorescencia es un ciato.

Fruto : Tricoco (con 3 cocos)

Género : Euphorbia, Ricinus.

\subsubsection{FAMILIA MALVACEAE}

Arbustos o hierbas mucilaginosas. Tallo fibroso. Hojas simples, alternas. Flores hermafroditas, actinomorfas con calículo. Androceo monadelfo.

Fruto : Cápsula o aquenio.

Géneros : Abutilon, Anoda

\subsubsection{FAMILIA UMBELLIFERAE (APIACEAE)}

Plantas herbáceas con canales secretores de esencias. Tallos parcialmente fistulosos. Hojas compuestas o pinnatisectas. Inflorescencia en umbela simple o compuesta. Fruto esquizocarpo (Dos mericarpos).

Género : Apium

\subsubsection{FAMILIA PRIMULACEAE}

Especies herbáceas. Hojas simples. Flores hermafroditas, pentámeras.

Fruto : Cápsula (Pixidio).

Género : Anagallis.

\subsubsection{FAMILIA ASCLEPIADACEAE}

Plantas laticíferas. Hojas opuestas o verticiladas, sin estípulas. Flores solitarias o en cimas corimbiformes. Con ginostegio.

Fruto : Folículo.

Género : Asclepias.

\subsubsection{FAMILIA CONVOLVULACEAE}

Plantas laticiferas, trepadoras. Hojas simples alternadas. Flores actinomorfas, hermafroditas, acampanadas.

Fruto : Cápsula dehiscente por cuatro valvas.

Géneros: Convolvulus, Ipomoea.

\subsubsection{FAMILIA VERBENACEAE}

Arboles, arbustos o hierbas. Tallo tetragonal. Hojas simples, opuestas o verticiladas. Flores pequeñas, zigomorfas. Estilo ginobásico o ter minal. Inflorescencia: Capituliforme o espiciforme.

Fruto : Esquizocarpio (Formado por 2 mericarpos, monospermos).

Género : Verbena

\subsubsection{FAMILIA SOLANACEAE}

Pequeños árboles, arbustos o hierbas. Tallo con hojas, muchas veces con olor fuerte y característico. Hojas simples o compuestas. Flores de corola rotácea, tubular o infundibiliforme.

Fruto : Cápsula o baya pluriseminada.

Género : Datura, Nicotiana, Nycandra.

\subsubsection{FAMILIA PLANTAGINACEAE}

Especies arrosetadas. Hojas simples curvinervias. Espiga con flores pequeñas.

Fruto : Cápsula (Pixidio)

Género : Plantago. 


\subsubsection{FAMILIA COMPOSITAE}

Plantas herbáceas o leñosas, a veces con látex. Hojas simples, alternas. Inflorescencia: En capitulo. Flores liguladas y tubulosas (Flósculos). Androceo: Con Estambres sinantéreos.

Fruto : Aquenio.

Género : Conyza, Eclipta, Galinsoga Heterospermum, Senecio, Taraxacum, Xanthium.

TRATAMIENTO SISTEMÁTICO

I. DIVISIÓN PTERIDOPHYTA

\section{FAMILIA EQUISETACEAE}

\section{Equisetum giganteum H.B.K}

Nombre vulgar :Perenne, rizomatosa, grácil, áspera o lisa de $30-50 \mathrm{~cm}$ de altura.

Tallos

Hojas

Esporófilos

Propagación

Hábitạt

: Por rizomas.

Articulados, delgados, aglomerados, macizos.

Escamiformes, rojizas unidas entre si, formando una vaina de 5 $10 \mathrm{~mm}$ de longitud.

En la extremidad de las ramas o tallos formando espigas etipitadas, oscuras de 8-15 mm ovoideoblongas, llevando numerosos esporangios en la cara inferior interna, conteniendo cada uno muchas esporas globosas.

Maleza : En cultivos inundados.

\section{DIVISIÓN SPERMATOPHITA}

A. Subdivisión Angiosgermae

a) Clase Monocotyledonae

\section{FAMILIA GRAMINEAE (POACEAS)}

\section{Bromus catharticus Vahl.}

Nombre vulgar : Cebadilla, cebadilla criolla, grama, soella.

Origen

:Norteamérica.
Planta

Tallo

Hojas

Inflorescencia

\section{Espiguilla}

Flor

Fruto

Propagación

\section{Echinochloa cruspavonis (H.B.K.) Schult}

Nombre vulgar : Moco de pavo.

Origen : América.

Especie

Anual de 0.40 - $1 \mathrm{~m}$ de altura, con cañas más o menos gruesas, erguidas o decumbentes en la base.

Hojas

Anual o perenne de $0.40-1 \mathrm{~m}$. de alto.

Vaina: Cerrada, glabra o ligeramente pubescente $4-10 \mathrm{~cm}$ de largo.

Lígula: Membranácea de 2-5 mm.

Lámina: Convoluta, plana, glabra o apenas pubescente de $15-35 \mathrm{~cm}$ de largo por 4-8 $\mathrm{mm}$ de ancho.

Panoja laxa colgantes de $10-20$ $\mathrm{cm}$. de largo con ramas inferiores divergentes, ramas inferiores más cortas con menor número de espiguillas.

Glumas: 5 - 11 flores, largamente pediceladas, desiguales, agudas, aquilladas, la superior de $7-10 \mathrm{~mm}$ nervada, la inferior nervada de 6 $9 \mathrm{~mm}$ de largo.

Glumelas : Lemma: Aquillada, glabra o apenas pubescente, brevemente bidentada aristada de 0.5 a $4 \mathrm{~mm}$, de longitud.

Palea: Membranáceatransparente, bicarenada entera o bidentada y ciliada, $2 \mathrm{~mm}$ de longitud.

: Hermafrodita.

Androceo: 3 estambres.

Gineceo: Estigma plumoso, estilo bífido, ovario súpero.

: Cariópside lineal - lanceolado 5 $7 \mathrm{~mm}$ longitud, adherido a las glumelas.

Vaina: Glabra, compresa.

Aurícula y Lígula: Ausentes. 
Lámina: Lineal, lanceolada de 10$20 \mathrm{~cm}$ de largo.

Inflorescencia

Espiguillas

Flor

Fruto

Propagación : Por semillas.

Poa annua $L$.

Nombre vulgar

Origen

Planta

Tallo

Hojas

Inflorescencia

Espiguillas
: Panoja formada por racimos espiciformes unilaterales, con el raquis persistente en el eje de la inflorescencia.

: Comprimidas dorsalmente, elípticas, aristadas con una flor hermafrodita, en la base un rudimento estéril.

Glumas: Desiguales.

Glumelas : Lemma granifera lisa cartilaginosa, abraza a la palea en la parte inferior y abierta en la extremidad.

: Con tres estambres y estigma terminal. Ovario globoso.

: Cariópside oval o elíptico, liso, acumulado pardo amarillento.

: Pasto de invierno.

: Es cosmopolita.

: Herbácea, menores de $25 \mathrm{~cm}$.

: Caña erguida, grácil, glabra.

: Aurículas: Ausentes.

Ligula: Membranosa, oblonga.

Vaina : Glabra o mas o menos pubescente, cerrada.

Lámina : Plana, plegada o convoluta en la extremidad de 2-5 $\mathrm{mm}$ de largo x 2-3 mm de ancho.

: Panoja laxa y contraida.

: 2-9 flores, comprimidas lateralmente, menores de $1 \mathrm{~cm}$. Raquillas articuladas arriba de las glumas y entre las flores.

Glumas : Agudas, aquilladas, la inferior 1-3 nervada, la superior 3nervada.

Glumelas :

Lemma : Aquillada 5 - nervada nútica.
Palea: Biaquillada, ordinariamente bidentada, más corta que la lemma.

Flores : Hermafroditas.

Fruto : Cariópside triangular, glabro, con surco ventral.

Propagación : Mediante semillas.

\section{Pennisetum clandestinum hochst}

Nombre vulgar : Kikuyo.

Origen : Africa.

Planta : Perenne, provista de largos estolones y profundos rizomas, hasta de tres o más metros de largo.

Tallo

: Los rizomas llevan dos clases de tallos:

Estériles: de entrenudos cortos y hojas largas.

Fértiles: en que las inflorescencias crecen en la axila de las hojas.

Hojas : Lígula: Pestañosa.

Vaina: Imbricada, pubescente.

Lámina: Lineal, plana de $3-18 \mathrm{~cm}$ de longitud por 3-6 mm de ancho. Haz y envés pubescentes.

Inflorescencia : Constituida por 2-4 espiguillas subsésiles, incluidas en las vainas foliares superiores.

Espiguillas $\quad$ : Lanceoladas: Llevan 2 flores: una superior y estéril, la superior fértil.

Glumas: 3, la inferior pequeña, la segunda tan larga como la espiguilla y la tercera (lemma de la flor masculina o estéril) igual a la segunda, ordinariamente con una palea axilar anterior fértil con la lemma papirácea acuminada.

Flor : Superior:

Hermafrodita con 3 estambres, destacándose sus filamentos largos que sobresalen del follaje.

Fruto

: Cariópside, incluido en las glumelas. 
Propagación : Por rizomas.

\section{Setaria verticillata (L) beauv}

Nombre común : Cola de zorro, pega-pega.

Origen : Europa.

Planta : Herbácea hasta $50 \mathrm{~cm}$ de altura, cañas geniculadas, erguidas nudosas, ramificadas desde la base.

Hojas : Envainadoras.

Ligula : Corta, membranácea.

Lámina: Plana, lineal - lanceolada de $10-20 \mathrm{~cm}$ de largo más o menos pilosas.

Inflorescencia : Panoja densa, espiciforme.

Espiguillas

: Con setas, involucrales. Las espiguillas oblongo - elípticas.

Glumas: Desiguales.

Fruto : Cariópside ovoide, rugoso transversalmente.

Propagación : Por semillas

\section{Sorghum halepense (L.) pers}

Nombre vulgar : Grama china, sorgo de alepo, pasto ruso, pasto Johnson, maicillo, sorgillo, canutillo, sorgo.

Origen : : Asia tropical, Mediterráneo.

Planta : Perenne de 1 a $1.5 \mathrm{~m}$. de altura.

Tallo · : Rizomas largos y abundantes, horizontales estoloniformes, cañas floriferas erguidas, huecas, glabras.

Hojas : Ligula : Membranosa, ciliada, 1 $1.5 \mathrm{~mm}$ de longitud.

Vaina : Redondeadas, glabra, 10 $\mathrm{cm}$ de largo.

Lámina : Lineal, ancha, glabra de $20-40 \mathrm{~cm}$ de largo por $1-2 \mathrm{~cm}$ de ancho, glabra. Margen algo escabroso (nervadura central prominente).

Inflorescencia : Panoja laxa, piramidal u oblonga, generalmente rojiza de $15-25 \mathrm{~cm}$ de largo.
Espiguilla

: Comprimidas, una fértil y otra estéril.

Espiguilla fértil : Hermafrodita, sésil, caediza a la madurez por desarticularse en su base. $5 \mathrm{~mm}$ de longitud, retorcida, geniculada.

Palea: Hialina breve.

Espiguilla estéril : Masculina, pedicelada $4 \mathrm{~mm}$ de longitud.

Glumas : Casi iguales, coriáceas, tridentadas, núticas, sobrepasando las flores.

Glumelas: Lemma : Aristada, arista de mas o menos $1 \mathrm{~cm}$.

Flor

Androceo: 3 estambres.

Gineceo : Estigmas plumosos, 2 estilos cortos, ovario globoso súpero.

Fruto

Cariópside cubierto por las glumas, obovado, comprimido, 1.5 - $2.5 \mathrm{~mm}$ de largo, de color castaño oscuro.

Propagación : Por semillas y estolones.

\section{Sporobolus indicus $L$.}

Nombre vulgar : Paja de hueso, serrillo.

Origen : Vaina: Glabra.

Lámina :Lineal, aguda, glabra, involuta de 3 - $4 \mathrm{~mm}$ de ancho.

Inflorescencia : Panoja laxa espiciforme, de 10 $35 \mathrm{~cm}$ de largo, ramas adpresas o ascendentes con espiguillas de 1.5 $-1.8 \mathrm{~mm}$ de largo.

Espiguilla

Una flor con raquilla articulada arriba de las glumas.

Glumas : 1-nervadas.

Glumelas : 
Lemma : 3 - nervada, aguda, nútica.

Palea : 2 - nervada aquillada igual o menor que la lemma, entera o dividiéndose en dos partes por la presión del fruto.

Lodículas 2.

Flor

: Hermafrodita.

Androceo : 1 - 3 Estambres.

Fruto

: Cariópside comprimido o globoso, sin surco, mucilaginoso.

Propagación : Por semillas.

FAMILIA LILIACEAE

\section{Nothoscordum inodorum (SIT) nichols}

Nombre vulgar : Cebollino, lágrima de la virgen.

Origen

: América.

Planta

Hojas

Inflorescencia

Flores

Androceo

Gineceo

Fruto
: Geofita, con bulbos tunicados, ovoideos de $1-2 \mathrm{~cm}$ de diámetro, con numerosos bulbillos circundantes.

: Fasciculadas, carnosas, blanquecinas.

: Basales, lineales, planas, carnosas, paralelinervias de 20 $30 \mathrm{~cm}$ de longitud por $0.5-1 \mathrm{~cm}$ de ancho.

Escapo floral verde de $20-30 \mathrm{~cm}$ de altura. Umibela con 8 a 15 flores pediceladas.

: Hermafroditas, actinomorfas, 8 $10 \mathrm{~mm}$ de longitud, perigonio blanco.

Sépalos: 6 elípticos u ovadoelípticos con una línea longitudinal rosado-violácea.

: Estambres 6 filamentos linealoblongos. Anteras elípticas.

Estigma globoso, estilo filiforme, ovario súpero tricarpelar, trilocular con varios óvulos en cada lobulo.

Cápsula obovoide, negra de 7-5 $\mathrm{mm}$ de largo, dehiscente loculicida.
Propagación : Por semillas y por bulbillos.

\section{FAMILIA POLYGONACEAE}

Polygonum aviculare $L$.

Nombre vulgar : Cien nudos, lengua de pájaro.

Origen

: Cosmopolita.

Planta

Tallo

Hojas

: Herbácea, anual, decumbente, de menos de $0.50 \mathrm{~cm}$ de altura.

: Delgado, estriado, simple, ramificado.

: Simples, alternas, lineales lanceoladas o elípticolanceoladas, sésiles, agudas, enteras, alternadas, peninervias, glaucas. Miden $0.5-4 \mathrm{~cm}$ de longitud. Hojas superiores más pequeñas que las inferiores. Con estípulas membranosas envainadoras, llamadas ócreas.

Inflorescencia : Flores solitarias axilares, 2 - 5 en la axila de las hojas, blanquecinas, verdosas o rosadas.

Flores

Perianto

Hermafroditas, actinomorfas, pequeñas, pedunculadas o sésiles.

: Petaloideo o semiherbáceo, con divisiones profundas en número de 5 , casi iguales.

Androceo : Estambres en número de 5 - 8, libres sobre los miembros del perigonio o alternando con éstos.

Gineceo

: Estigmas 2 - 3 capitados, estilos 2 - 3 , ovario súpero comprimido o trígono, unilocular, uniovulado.

Fruto

: Aquenio lenticular o trigonal, recubierto por el perianto.

Semillas

: Trigonales, estriadas, pequeñas.

Propagación : Por semillas

\section{Rumex crispus L.}

Nombre vulgar

Origen

: Lengua de vaca.

Planta
: Europa - Africa.

: Perenne de 30 - $80 \mathrm{~cm}$ de longitud, tallo poco ramificado, estriado con ócreas escariosas cilíndricas. 
Hojas

Inflorescencia

Flores

Perigonio

Androceo

Gineceo

Fruto

Propagación : Por semilla.

\section{FAMILIA URTICACEAE}

\section{Urtica urens $\mathrm{L}$.}

Nombre vulgar : Ortiga.

$\begin{array}{ll}\text { Origen } & : \text { N. Temp. } \\ \text { Planta } & : \begin{array}{l}\text { Anual de } 15-50 \mathrm{~cm} \text { de altura, tallo } \\ \text { erguido, ramificaciones desde la } \\ \text { base. }\end{array}\end{array}$

Hojas

: Simples, opuestas, elípticas, ovoides, pecíolo de $1-3 \mathrm{~cm}$ de largo, borde irregular, agudamente aserrada, 3-5 nervada.

Inflorescencia : Axilares o terminales. racimos más cortos que el pecíolo. Flores unisexuales.

Flores masculinas : Cáliz: Sépalos 4 con pelos urticantes.

Corola: Ausente

Androceo : Estambres 4 con filamentos largos, replegados y elásticos. Anteras redondas, dorsifijas.

Flores femeninas : Perianto: 4 piezas, 2 grandes y 2 pequeñas.

Gineceo

: Estilo reducido, estigma en pincel. Ovario esférico súpero. Aquenio de $1.6 \mathrm{~mm}$ de longitud.

Fruto

Seco, unilocular, monospermo, indehiscente y recubierto por el perianto. Ovado, aplanado, amarillo.

Semilla

Con cotiledones dorsiformes erizados.

Propagación : Por semillas.

\section{FAMILIA CHENOPODIACEAE}

\section{Chenopodium album $\mathrm{L}$.}

Nombre vulgar : Quinua silvestre.

Origen : N. Temp.

Planta

: Herbácea, pruinosa de $0.30-1 \mathrm{~m}$ de altura.

Tallo

: Erguido, acanalado, glabro, grueso, ramificado, desde la base, con tintes rojizos.

Hojas

: Simples. Rómbico ovoides, ovalaladas, lanceoladas, agudas, sinuado lobadas o dentadas, penninervias, pruinosas en haz y envés de 2.5 - $8 \mathrm{~cm}$ de largo por 3 $\mathrm{cm}$ de ancho.

Inflorescencia : Panículas espiciformes axilares y terminales o glomérulos axilares.

Flores

Pequeñas, verdosas, con manchas rojizas al madurar.

Cáliz : Sépalos 5, carenadas, soldados en la base, pruinosos.

Corola : Ausente.

Androceo

5 estambres exertos, insertados 
en el fondo del perianto como anillo, filamentos gruesos, transparentes, anteras basifijas.

Gineceo

: Estigmas 2, estilo corto, ovario súpero, unilocular, un óvulo basal.

Semilla

: Lenticular, negra algo lustrosa de 1-1.2 mm. de diámetro.

Propagación : Por medio de semillas.

\section{Alternanthera pubiflora (Benth.) kuntze}

Nombre vulgar : Siempre viva, hierba blanca.

Origen

: América.

Planta

Hojas

Inflorescencia

Flores

Androceo

Gineceo

Fruto

Semillas

Propagación
Perenne, erguida o rastrera.

: Simples, opuestas, cortamente pecioladas, peciolos de $3-5 \mathrm{~mm}$ de longitud, ovoides u ovoideselipticas, agudas, mucronadas, alternadas, enteras, pubescentes, penninervias. Haz verde purpúreo. Envés púrpura, limbo de $1.5-5 \mathrm{~cm}$ de largo por $0.8-2.5 \mathrm{~cm}$ de ancho.

: Espigas capituliformes, globosas, axilares, pedúnculos de 2 - $4 \mathrm{~mm}$ de longitud.

Pequeñas, blanquecinas, hermafrodita, protegidas por una bráctea y 2 bracteolas.

Perigonio compuesto de 4 - 5 sépalos iguales o desiguales libres de $5 \mathrm{~mm}$ de longitud.

: Estambres 3 - 5 filamentos unidos en su base, formando una cúpula más o menos alargada. Anteras monotecas, estaminodios, alternando con los estambres reducidos a simples filamentos.

: Estigma capitado. Estilo nulo o subnulo, ovario súpero unilocular, uniovulado.

: Utrículo, indehiscente, rodeados por los sépalos persistentes.

: Lenticulares.

: Por semilla.

\section{FAMILIA AMARANTHACEAE}

Amaranthus dubuis mart.

Nombre vulgar : Yuyo hembra, bledo.

Origen : América.

Planta : Herbácea de $30-70 \mathrm{~cm}$ de altura.

Tallo : Erguido, ramificado.

Hojas

: Simples, alternas, largamente pecioladas, rómbico - ovadas, ápice obtuso.

Inflorescencia : Espigas terminales y axilares.

Flores

: Unisexuales, verdosas o blanquecinas. Brácteas ovadas, agudas y mucronadas de tamaño igual o menor que los tépalos.

Flores masculinas: Con 5 tépalos ovado - oblongos y 5 estambres.

Flores femeninas: Con tépalos oblongo espatulados, ovario súpero.

Fruto

Utrículo rodeado por el perigonio persistente, pericarpio membranáceo, dehiscente transversalmente.

Propagación : Mediante semillas.

\section{Amaranthus celosioides HBK}

Nombre vulgar : Yuyo, bledo.

Origen

: América

Planta

: Herbácea erguida de $50 \mathrm{~cm}$ de altura.

Tallo

: Grueso, glabro, ramificado, verdepúrpura.

Hojas

: Simples, alternas, peciolos largos, ovadas-lanceoladas u ovadorómbicas, penninervias, ápice mucronado.

Inflorescencia : Espigas cortas, densas. Brácteas más cortas que los tépalos, membranosas, ovadas.

Flores

: Flores masculinas: con tépalos desiguales, espatuladas verdepúrpura en su parte dorsal, presentando 5 estambres.

Flores femeninas : Con 5 tépalos desiguales, estigma 
trifurcado, ovario súpero oblongo.

Fruto : Utrículo con superficie rugosa.

Semillas : Ovoide - lenticular, negras 0 pardas, brillantes.

Propagación : Mediante semillas.

\section{FAMILIA RANUNCULACEAE}

\section{Clematis vitalba}

Nombre vulgar : Cabellos de ángel. Hierba de pordioseros.

Origen : Europa, norte de Africa y sudoeste de Asia.

Planta : Arbustiva trepadora.

Hojas : Compuestas imparipinnadas con 3 - 9 foliolos, aovadas, agudos de $5-7 \mathrm{~cm}$ de largo enteras o dentadas.

Inflorescencia : Panojas auxilares.

Flores

Androceo : Numerosos estambres.

Gineceo

: Estigma filiforme, glabro o pubescente, estilo corto, ovario con numerosos carpelos uniovulados.

Fruto : Aquenios plumosos.

Propagación : Por semillas.

FAMILIAPAPAVERACEAE

Argemone subfusiformis OWNB (Argemone Mexicana Auct. div. non L.)

Nombre vulgar : Cardo santo, cardo amarillo, cardo blanco, ccarhuinchunca, ccarhuinchu.

Origen : América.

Planta : Anual herbácea, erguida, laticifera, ramificada de $0.25-1 \mathrm{~m}$ de altura, glauca glabra y totalmente espinosa.

Hojas

: Simples alternas, sésiles, oblanceoladas, angostas, borde sinuado-pinnatifidas y de borde espinoso de $10-25 \mathrm{~cm}$ longitud por 3-10 cm de ancho, hojas superiores amplexicuales. Hojas basales subarrosetadas.

Inflorescencia : Flores grandes solitarias, terminales. Pedúnculo corto o flores subsésiles.

Flores : Hermafroditas, actinomorfas.

Cáliz: Sépalos 2 caducos.

Corola : Pétalos 4 - 6, amarillos caducos obovados.

Androceo

: Estambres numerosos, libres. Filamentos filiformes. Anteras lineales, de dehiscencia longitudinal.

Gineceo : Estigma púrpura cuadrífido, estilo corto, ovario súpero, pluricarpelar, 1-locular, multiovulado.

Fruto

: Cápsula espinosa, oblonga, de 4 $5 \mathrm{~cm}$ de largo. Dehiscente por valvas apicales.

Semillas : Numerosas, esféricas u ovoides, negras, con ángulos y cresta irregular lateral pardo-negruzca de 2-2.5 $\mathrm{mm}$ de largo.

Propagación : Por semillas.

\section{FAMILIA CRUCIFERAE}

\section{Coronopus didymus (L.) Smith}

Nombre vulgar : Quimpe.

Origen : Sudamérica.

Planta : Herbácea, pubescente con tricomas simples, de $30-40 \mathrm{~cm}$ de alto.

Tallo : Decumbente, hojoso.

Hojas : Simples de $9-10 \mathrm{~cm}$ de largo, largamente peciolada. Pinnantipartida o pinnatisectas con lóbulos dentados.

Inflorescencia : Axilar o terminal. Racimos compactos o laxos.

Flores : Pequeñas, hermafroditas, actinomorfas.

Cáliz : Regular, conformado por 
cuatro sépalos.

Corola : Con cuatro pétalos regulares, blancos que sobresalen poco del cáliz o ausentes.

Androceo

: Con 2 - 4 estambres.

Gineceo

Fruto

Semillas

Propagación : Por semillas.

\section{FAMILIA FUMARIACEAE}

\section{Fumaria capreolata L.}

Nombre vulgar : Anisillo, fumaria, flor de pajarito, perejilillo.

Origen : Europa.

Planta

: Herbácea, anual, erguida o decumentes o trepadora, sin látex. De $35-40 \mathrm{~cm}$ de altura.

Tallo

Hojas

Cilindrico, ramificado desde la base, voluble.

Alternas de 5 - $6 \mathrm{~cm}$ de largo, a menudo enroscables, profundamente divididas o compuestas, verde - azuladas o glaucas, con 5 - 7 folíolos, cada uno de ellos trifurcado.

Inflorescencia : Racimos más o menos compactos, con numerosas flores pequeñas.

Flores

: Hermafroditas, zigomorfas.

Cáliz : Dialisépalo, 3 - $5 \mathrm{~mm}$ de largo. Sépalos 2, escamiformes, caducos, blanquecinos.

Corola : Dialepétala, $7 \mathrm{~mm}$ a $1 \mathrm{~cm}$ de largo dispuestos en 2 verticilos, los del verticilo externo o uno solo de pétalos 4 , libres blanquecinos, el globoso o espolonado en la base, con una mancha púrpura en el ápice.

Androceo

$\begin{array}{ll} & \text { trifurcados. } \\ \text { Gineceo } & \text { Estigma 2, estilo filiforme, ovario } \\ & \text { súpero, unilocular, con } \\ \text { placentación parietal. }\end{array}$

Fruto

: Cápsula indehiscente, $2 \mathrm{~mm}$ de longitud, semejante a una pequeña silicua globosa con una sola semilla.

Propagación : Mediante semillas.

\section{FAMILIA LEGUMINOSAE (FABACEAS)}

Crotalaria incana $L$.

Nombre vulgar : Cascabelillo. Chsallchsallcha

Origen

: América tropical.

Planta

: Herbácea de $1 \mathrm{~m}$ de altura.

Tallo

Hojas

: Ramificado, pubescente.

: Compuestas trifoliadas. Folíolos ovados u obovados. Estípulas pequeñas, setáceas.

Inflorescencia : Racimo terminal.

Flores : Medianas o grandes.

Cáliz: Persistente, acampanados 5 - lobado.

Corola :Papilionácea color amarillo-pardo.

Androceo : Estambres 10 monadelfos.

Gineceo

: Estigma apical estilo curvo. Ovario súpero.

Fruto

: Legumbre coriácea, inflada, densamente pubescente pardusca. Cuando los frutos se mueven producen un ruido como de serpiente de cascabel.

Semillas

:Pequeñas, reniformes verde parduscas.

Propagación : Por semillas.

\section{Medicago polimorpha L.}

Nombre vulgar : Trébol de carretilla. Trébol.

Origen

: Sur de Europa.

Planta

: Especie herbácea, potrada o ascendente, mide $40-50 \mathrm{~cm}$ de altura. 
Tallo

Hojas

Inflorescencia

Flores

Gineceo

Fruto

Semillas

Propagación

Delgados, poco ramificados.

Compuestas trifoliadas. Folículos obcordados dentados, con estipulas laciniadas ovalolanceoladas.

: Cortos racimos solitarios axilares 1 - 7 flores.

\section{: Pequeñas}

Cáliz: Acampanado 5 dentado.

Corola: Papilionácea

: Estambres 10, diadelfos.

: Estigma más o menos capitado, estilo corto, ovario súpero piloso.

: Vaina con 2 - 6 espiras, reticuladas con púas ganchosas café-negras a la madurez.

: Reniformes, lisas, amarillo pardo.

\section{ESPECIE FORRAJERA}

\section{Trifolium repens $L$.}

Nombre vulgar : Trébol.

\section{Origen}

Planta

Tallo

Hojas

Inflorescencia
: Europa.

: Herbácea perenne o a veces por la sequia anual o bienal, subglabra, hasta $30 \mathrm{~cm}$ de largo.

Rastreros estoloniformes, radicantes en los nudos de 15 - 30 $\mathrm{cm}$ de largo.

Compuestas trifoliadas, largamente pecioladas. Peciolos delgados débiles, glabros de 1.5 $20 \mathrm{~cm}$ de largo. Folíolos acodados, anchamente cuneados, denticulados diminutamente, en el centro una mancha blanquecina en forma de $V$ en el haz, glabras en ambas superficies, de 6-18 $\mathrm{mm}$. de largo sostenidos por peciolos breves.

\section{Estipulas membranosas} lanceoladas, soldadas al peciolo de 6 - $10 \mathrm{~mm}$ de largo.

: Capítulos multifloros axilares, con
Flores

largo pedúnculo, superando las hojas de $1.5-2.5 \mathrm{~cm}$ de diámetro.

: Numerosas de 8 - $15 \mathrm{~mm}$ de largo.

Cáliz: Persistente, campanulado, 5 dentado, 10 nervado.

Corola : Papilionácea. Pétalos blanco - rosados, ocasionalmente púrpura.

Androceo : Estambres 10, diadelfos.

Gineceo

Con estilo filiforme, estigma capitado y ovario súpero monocarpelar.

Fruto

Semillas

Vaina oblonga. Pluriseminada dehiscente.

Amarillas - rojizas, muy pequeñas, cordiformes, de $0.9-1.2 \mathrm{~mm}$ de longitud.

Propagación : Por semillas.

\section{Vicia graminea Smith}

Nombre vulgar : Alverjilla, kita Itacco, occoctijan, tarhuitarhui.

Origen : América.

Planta

Herbácea anual, trepadora por medio de zarcillos foliares de tallos endebles.

Hojas : Compuestas imparipinnadas, con 2 - 3 pares de foliolos. Foliolos alternos, $2.5-3 \mathrm{~cm}$ de largo por 2 - $4 \mathrm{~cm}$ glabros, oblongo lineales, planos, ápice obtuso. Mucronado. Foliolo terminado en un zarcillo hasta $5 \mathrm{~cm}$ de longitud.

Estípulas cordiformes mucronadas de 3 - 4 mm de longitud.

Inflorescencia : Racimos largos, axilares. Pedúnculo con 3 - 4 flores.

Flores

Papilionáceas, zigomorfas, $1 \mathrm{~cm}$ de longitud pediceladas.

Cáliz: Campanuláceo, gamosépalo, 5 sépalos dentados.

Corola : Papilionácea. Pétalos 5 , violáceos o blanco-violáceos.

Androceo : Estambres 10-diadelfos. 
Gineceo : Estilo breve incurvo, filiforme en ángulo neto con el ovario líneal, monocarpelar, monocular, estigma plumoso. Ovario súpero.

Fruto

: Legumbre lineal, recto, dehiscente, 2 - 8 seminada de 2 - $3 \mathrm{~cm}$ de longitud.

Semilla : Esférica.

Propagación : Por semillas.

\section{FAMILIA OXALIDACEAE}

\section{Oxalis cernua thunberg}

Nombre vulgar : Vinagrillo, trébol, buttercup.

Origen : Sudáfrica.

Planta

Hojas

Inflorescencia

Flores

Androceo

Gineceo

Fruto

Semilla
: Anual glabra de $15-20 \mathrm{~cm}$ de altura. Sin tallos, con bulbillos en la base, erguidos.

: Compuestas trifoliadas. Folíolos cordiformes muy escotados con puntuaciones rojizas, base cuneada, peciolos de $15-20 \mathrm{~cm}$ de longitud.

: Cimosa (15 flores) Pedúnculos de hasta $50 \mathrm{~cm}$ de longitud.

: Hermafroditas, actinomorfas, con pedicelos de diferente longitud.

Cáliz: Sépalo 5, imbricados, poco concrecente en la base. hipoginos, poco concrecentes en la base de $2 \mathrm{~cm}$ de longitud.

: Estambres 10 fértiles, cónicos en la base dispuestos en dos filas, los 5 externos más pequeños que los interiores. Filamentos tienen anteras con dehiscencia longitudinal.

: Estigmas capitados, estilos cortos ovario súpero pentacarpelar, pentalocular, con numerosos óvulos en cada lóculo.

: Cápsula loculicida con valvas persistentes que contienen semillas que se separan violentamente.

Ovoides, aplastadas y estriadas.
Corola: Pétalos 5, amarillo intenso

Propagación : Por semilas.

\section{Oxalis corniculata L.}

Nombre vulgar : Vinagrillo, vinagrillo rastrero, trébol.

Origen

Planta

Hojas

Inflorescencia

Flores

Androceo

Gineceo

Fruto

Semilla

Propagación

\section{FAMILIA ZYGOPHYLLACEAE}

\section{Tribulus terrestris $\mathrm{L}$.}

Nombre vulgar : Abrajo, tribolo, anocar cchapi.

Origen

: O.W. tropics. Sur de Europa.

Planta

Herbácea, postrada, de 0.50 - 1m. de largo.

Tallos
Planta anual, pubescente, rastrera de $10-30 \mathrm{~cm}$ de longitud, con tallos rastreros, sin bulbillos, débiles, ramosos, verde vinosos, ramificados en la base.

Compuestas con 3 folíolos, verdes con tintes rojizos, poco escotados, base cuneada, peciolos pubescentes de $2-4 \mathrm{~cm}$ de longitud. Estipulas pequeñas, oblongas unidas al peciolo en sus 2/3 inferiores.

Cimosa 2-5 flores. Pedúnculos axilares de $1-2.5 \mathrm{~cm}$. de longitud.

Cáliz: Sépalos 5, ligeramente concrescentes en la base, imbricados.

Corola : Pétalos 5, amarillos hipoginos algo concrescentes en la base, obavado oblongos de 5 $10 \mathrm{~mm}$ de longitud.

: Estambres 10,5 largas y 5 cortas.

Estigmas capitados, 5 estilos, ovario pentacarpelar.

: Cápsula cilíndrica.

: Marrón, elíptica comprimida.

: Por semillas y vegetativamente.
Cilindricos, verde o verde pardusco, ramificado, pubescente. 
Hojas

: Paripinnadas, pecioladas, peciolos pubescentes de $2-3 \mathrm{~mm}$ de longitud, 10 - 14 foliolos mucronadas, pubescentes más en el envés de 4 - $10 \mathrm{~mm}$ de largo por 1 - $7 \mathrm{~mm}$ de ancho.

Estípulas lanceoladas filosas de 4 $\mathrm{mm}$ de longitud.

Inflorescencia : Flores solitarias axilares, pedunculadas, pedúnculos foliosos de 4 - $12 \mathrm{~mm}$ de largo.

Flores

: Hermafroditas, actinomorfas, pequeñas.

Cáliz: Sépalos 5 lanceoladas, caducos, agudos de $5 \mathrm{~mm}$. de longitud, pubescente.

Corola : Pétalos 5 oblongos más largos que el cáliz, amarillos de 6 - $7 \mathrm{~mm}$ de largo.

Androceo

: Estambres 10 libres iguales a la corola o exsertos, filamentos filiformes, anteras oblongas, dehiscentes longitudinalmente.

Gineceo

: Estigma con 5 radios, estilo muy corto. Ovario súpero, sésil, pubescente.

Fruto : Cápsula pentámera pubescente de $10 \mathrm{~mm}$ de ancho con 5 mericarpos, cada uno con 2 espinas y distribuidas en estrella.

Semilla : Largas y punzantes y otras más cortas. Cada mericarpo lleva 2 - 3 semillas separadas por tabiques transversales.

Propagación : Por semillas.

\section{FAMILIA EUPHORBIACEAE}

\section{Euphorbia heterophylla L.}

Nombre vulgar : Lechera, flor de pascua de monte, pascua huchapurga.

Origen : Sudamérica.

Planta : Monoica, herbácea, anual erguida, laticifera de $0.50-0.70 \mathrm{~cm}$ de altura.

Tallo : Cilindrico, poco ramificado, verde rojizo, pubescente.
Hojas

Simples, las inferiores alternas, superiores opuestas, base oblicua ligeramente, enteras o dentadas, penninervias, elipticas, pubescentes en las superficies adaxial y abaxial. Miden $1.5-5 \mathrm{~cm}$. de longitud.

Inflorescencia : Ciatos agrupados en cimas biparas.

Flores : Pequeñas unisexuales.

Masculinas : Numerosas en los ciatios, con un solo estambre. Filamento articulado. Antera globosa, dehiscente longitudinalmente. Una vez en el centro del ciato, estilos cortos, estigmas trífidos.

Femeninos : Ovario súpero, tricarpelar, largamente pedunculado.

Fruto

: Cápsula glabra esquizocárpica, péndula que sobresale del involucro de $5 \mathrm{~mm}$ de longitud.

Semilla

: Ovoides, pardas oscuras, tuberculadas, $2 \mathrm{~mm}$ de longitud.

Propagación : Por semillas.

\section{Euphorbia hypericifolia L.}

Nombre vulgar : Hierba de la golondrina, lechera, leche huajai.

Origen : Tropical.

Planta

: Herbácea, anual, erguida, laticifera de $0.35-0.40 \mathrm{~cm}$ de altura.

Tallo

: Cilíndrico, glabro o ligeramente pubescente, rojizo a morado. Ramas que nacen de las axilas de hojas opuestas.

Hojas : Simples, opuestas, con peciolos cortos, 1 - $3 \mathrm{~mm}$ de longitud, oblongas, elípticas, agudas u obtusas, redondas, brevemente aserradas, penninervias obtusas, glabras en el haz y ligeramente pubescentes en el envés, de 1-3 cmts de longitud por $0.5 \mathrm{~cm}$ de ancho. 
Inflorescencia : Ciatos en cimas terminales o axilares.

Flores : Pequeñas, unisexuales.

Estigma y estilo trifido. Ovario súpero, tricarpelar, trilocular pubescente.

Fruto : Cápsula ovoide.

Semillas : Ovoides, pardo amarillentas.

Propagación : Por semillas.

\section{Euphorbia hirta L.}

Nombre vulgar : Hierba de la golondrina, golondrina, lechera, yerba colorada, urpai - micuna.

Origen : América tropical.

Planta : Monoica, herbácea, anual, laticifera, erguida o decumbente, pubescente, de 15 ó $25 \mathrm{~cm}$.

Tallo : Cilíndrico, delgado, ramificado, rojizo pubescente.

Hojas : Simples, opuestas, peciolos de $1.15 \mathrm{~cm}$ de largo, oblongo lanceoladas, agudas, diminutamente crenadas base oblicua, penninervias, haz pubescente, envés cano pubescente. De 1 $2.5 \mathrm{~cm}$ de longitud por $0.5 \mathrm{~cm}$ de ancho.

Flores : Pequeñas, unisexuales

Flor : Un estambre pequeño. Filamento articulado. Antera globosa.

Flor : Estigmas bífidos, estilos cortos, ovario súpero tricarpelar, trilocular.

Fruto

: Cápsula esquizocárpica, péndula que cae fuera del involucro conteniendo 3 logias monospermas, de $1 \mathrm{~mm}$ de longitud.

Semillas : : Rojizas, ovoides-trigonas, 0.3-0.5 $\mathrm{mm}$ de longitud.

Propagación : Por semillas.

\section{Euphorbia peplus L.}

Nombre vulgar : Albahaca venenosa, albahaquilla, lechera, lechetrezna, pichoga, siempre verde, mariquilla.

Origen : Europa y Asia.

Planta

Monoica, herbácea, anual, erguida, laticifera de $20-35 \mathrm{~cm}$ de altura.

Tallo

Herbáceo, cilindrico, verde, glabro, ramificado en la parte superior.

Hojas

Simples, glabras, las inferiores alternas obovadas, enteras las superiores, opuestas, sésiles o deltoideo ovadas, enteras de 0.5 $1.8 \mathrm{~cm}$ de longitud por $0.3-1 \mathrm{~cm}$ de ancho.

Inflorescencia : Ciatos solitarios o agrupados en cimas con brácteas involucrales.

Flores

: Pequeñas, unisexuales. Estambres, 4.

: Estigma y estilo trífido. Ovario súpero trilocular, triloculado, glabro.

Fruto : Cápsula globosa, glabra, de $2 \mathrm{~mm}$ de longitud, tres cocos monospermas, crestados en el dorso.

Semillas

: Oblongas, obovoide, de $1.3 \mathrm{~mm}$ de largo, color gris perlado.

Propagación : Por semillas.

\section{Ricinus communis $\mathrm{L}$.}

Nombre vulgar : Higuerilla, tártago, ricino.

Origen : Africa.

Planta : Arbusto, monoico, hasta $2 \mathrm{~m}$ de altura, tallo leñoso, ramificado con nudos prominentes, entrenudos huecos, coloración verde o rojiza.

Hojas

: Grandes, simples de $15-35 \mathrm{~cm}$ de longitud, alternas, glabras, peciolo de 15 - $40 \mathrm{~cm}$ de largo, palmatipartidas, con 5 - 11 lóbulos, aserrado, palmatinervosas, de color verde a morado.

Inflorescencia : Racimos terminales. La especie es monoica. Las flores masculinas situadas en la base, las flores femeninas en el ápice. 
Flores : Unisexuales

Flor masculina : Cáliz:con 3 - 5 sépalos partidos.

Corola: Ausente.

Androceo

: Estambres numerosos.

Filamentos con ramificación arborescente, anteras globosas de dehiscencia longitudinal.

Flor femenina : Cáliz: Caduco.

Corola : Ausente.

Gineceo

: Ovario súpero tricarpelar, trilocular, tres estilos, estigma trifido plumosos.

Fruto

Semillas

:Cápsula ovoidal espinosa triseminadas.

: Carunculadas, oblongocomprimidas, lisas, lustrosas, moteados de color café, crema o gris. Endosperma y cotiledones desarrollados de $9-22 \mathrm{~mm}$ de largo 6 - $15 \mathrm{~mm}$ de longitud.

Propagación : Por semillas.

\section{FAMILIA MALVACEAE}

\section{Abutilon teophrasti}

Nombre vulgar : Malva, abutilon.

Planta

: Arbustiva, ramificada, pubescente (tricomas estrellados) de 1-1.5 m de altura.

Tallo

Hojas

\section{: Erguido, cilíndrico, verde}

: Simples, alternas, pecioladas (peciolo de 1-7 cm de longitud), cordiformes, agudas, dentadas, pubescentes en haz y envés de 2$12 \mathrm{~cm}$ de largo por $1-10 \mathrm{~cm}$ de ancho.

Inflorescencia : Flores solitarias axilares.

Flores
Androceo

Gineceo

Fruto

Semillas

Propagación

\section{Anoda cristata (L.) Schlecht}

Nombre vulgar : "Ruppu", malva cimarrona. pedúnculos de $2.5-5 \mathrm{~cm}$ de longitud. Sin calículo.

Cáliz: Dialisépalo, sépalos 5 , lobulados, turbinados, pubescentes de 1-2 cm de longitud.

Corola : Dialipétala. Pétalos 5, amarillos de $2 \mathrm{cms}$. de longitud.
Origen

Tallo

Hojas

Inflorescencia : Flores solitarias axilares, largamente pedunculadas, carecen de calículo.

Cáliz : Sépalos 5, lóbulos acuminados.

Corola: Pétalos 5, blancos.

Androceo : Estambres monadelfos.

Gineceo

: América (Méjico). Especie herbácea, erguida de $0.75 \mathrm{~cm}$ de altura.

: Cilíndrico, verdoso, ramificado.

: Simples, alternas, enteras, pecioladas, los peciolos $2-3 \mathrm{~cm}$ de longitud, triangular-hastadas. Estipulas pilosas.

: Estigmas capitados, estilos en igual número que carpelos, ovario súpero con muchos carpelos (hasta 20).

Fruto

: Esquizocarpo con muchos mericarpos (hasta 20), los cuales se dividen a la madurez.

Semilla
: Color negro, reniformes. 
Propagación : Mediante semillas.

FAMILIA UMBELLIFERAE (APIACEAE)

Apium laciniatum (Dc) Urb.

Nombre vulgar : Culantrillo.

Origen

: América.

Especie

: Herbácea, pequeña de $15 \mathrm{~cm}$ de altura.

Tallo : Cilindrico ramificado.

Hojas : Envainadoras, profundamente pinnatisectas, con lacinias laterales.

Inflorescencia : Umbela compuesta sin involucro.

Flores : Pequeñas.

Cáliz : Inconspicuo.

Corola : Dialipétalas, 5 pétalos blancos.

Androceo : Estambres 5.

Gineceo : Con ovario ínfero bicarpelar.

Fruto : Diaquenio. Los aquenios son ovoides, con el carpóforo entero.

Propagación : Por semillas.

\section{FAMILIA PRIMULACEAE}

Anagallis arvensis $\mathrm{L}$.

Nombre vulgar : Pimpinella escarlata anagallo.

$\begin{array}{ll}\text { Origen } & : \text { Europa. } \\ \text { Planta } & \text { : Herbácea, hasta } 30 \mathrm{~cm} \text { de altura. } \\ \text { Tallo } & : \begin{array}{l}\text { Ramificado desde la base, tetrago- } \\ \text { nal, ascendente o postrado y } \\ \end{array} \\ & \text { extendido. }\end{array}$

Hojas : Simples, opuestas, sésiles, ovales u oval-lanceoladas, borde entero, envés con puntos ocres oscuros, pennivervias de $1-2 \mathrm{~cm}$ de longitud de $0.5-0.7 \mathrm{~cm}$ de ancho.

Inflorescencia : Flores solitarias, axilares, largamente pedunculadas. $\mathrm{EI}$ pedúnculo mide de $1.2-4.5 \mathrm{~cm}$ de largo.

Flores : Hermafroditas, actinomorfas.

Cáliz: Sépalos 5, verdes, lineales, unidos en la base de $5 \mathrm{~mm}$ de longitud.

Corola : Pétalos 5, de color rojoanaranjado, libres lobulados, unidos en la base, igualando o sobrepasando el cáliz de 3.5 - 4 $\mathrm{mm}$ de longitud.

Androceo : Estambres 5, insertos en la base de la corola, más cortos que ella.

Gineceo

Estigma obtuso, estilo filiforme, ovario súpero esférico, con numerosos óvulos.

Fruto

Cápsula esférica (pixidio), glabra, coronada por el estilo. De $2 \mathrm{~cm}$ de longitud.

Semillas

Subtetraédricas elipticas de 1 - 1.3 $\mathrm{mm}$ de largo pardo-oscuras papilosas.

Propagación : Por semillas.

\section{FAMILIA ASCLEPIADACEAE}

\section{Asclepias curassa vica $L$.}

Nombre vulgar : Flor de seda, flor de la reina, flor de muerte, yerba de seda, leche, leche. bandera española, algodón de seda, quita solimán.

\section{Origen : América.}

Planta : Subfruticosa laticifera de 0.70 $1.50 \mathrm{~m}$ de altura.

Tallo

Erguido, ramificado, cilindrico, leñoso.

Hojas

Simples, opuestas, peciolo de 0.5 - $1 \mathrm{~cm}$ largo. lanceoladas de 6-16 cms largo, 1.4 - $3.5 \mathrm{~cm}$ de ancho. Penninervias, nervaduras prominentes en el envés.

Inflorescencia : Flores dispuestas en umbelas axilares o terminales paucifloras.

Flores

: Hermafroditas, actinomorfa.

Cáliz:Sépalos 5, lobulados, lóbulos angostos, lineales, acuminados, de $3-3.5 \mathrm{~mm}$ de longitud.

Corola : Pétalos 5, lobulados rojoanaranjados de $9 \mathrm{~mm}$. largo, ancho. Corona con lóbulos erectos. 
Androceo

: Estambres 5, los granos de polen de las anteras se sueldan formando una masa denominada polinia.

Gineceo

Fruto

Semillas

Propagación : Semillas.

\section{FAMILIA CONVOLVULACEAE}

Convolvulus arvensls $\mathrm{L}$.

Nombre vulgar : Corregüela, campanilla.

$\begin{array}{ll}\text { Origen } & : \text { N. temp. } \\ \text { Especie } & : \text { Herbácea, rastrera. } \\ \text { Hojas } & : \text { Simples, alternas, hastadas. Las } \\ & \text { primeras son oval-redondeadas. }\end{array}$

Flores : Solitarias axilares.

Cáliz : Visible, dividido hasta la base en cinco lóbulos, casi iguales.

Corola: Acampanada. Pétalos 5 , rosados o blancos, entera o sinuado lobada.

Androceo : Estambres 5, epipétalos.

Gineceo

: Estigma bifido, estilo filiforme, ovario súpero.

Fruto : Cápsula indehiscente, cada carpelo con dos semillas angulosas.

Propagación : Por semillas.

\section{IPOMOEA PURPUREA L. ROTH}

Nombre vulgar

: Auroras, campanilla, suspiros, bejuco.

Origen

\section{: América tropical.}

Hojas

(1)

Inflorescencia

Flores

Androceo

Gineceo

Fruto

Semillas

Propagación

\section{FAMILIA VERBENACEAE}

\section{Verbena littoralis H.B.K.}

Nombre vulgar : Verbena del campo.

\section{Origen}

Planta

Tallos

Hojas

Planta

\section{: América.}

: Herbácea anual de 0.50 - $1 \mathrm{~m}$ de altura.

: Tetrágonos, delgados, ramificados en la parte superior.

Simples, opuestas, sésiles o cortamente peciolados, decusadas de 4 - $8 \mathrm{~cm}$ de longitud por 1 de ancho. Hojas superiores 
liniceares o lanceoladas, agudas, dentadas, las superiores enteras, base.

Inflorescencia : Espiga cilíndrica, terminal corta.

Flores

: Pequeñas.

Cáliz : Breve, 5 sépalos dentados.

Corola : Gamopétalas, 5 pétalos lobados de color lila claro-violáceo.

Androceo : Estambres 4, didinamos epicorolinos.

Gineceo : Estigma 2, lobado, estilo largo, ovario súpero, bicarpelar con 4 lóculos.

Fruto

Esquizocarpo, a la madurez se separa en 4 mericarpos, cada uno con una semilla.

Propagación : Por semillas.

\section{FAMILIA SOLANACEAE}

Datura stramonium L.

Nombre vulgar : Belladona, chamico, datura, cojón del diablo, estramonio, toncotonco.

Origen : América.

Planta : Anual, glabra, erecta de $1 \mathrm{~m}$ de altura.

Tallo

Hojas

Cilindrico, con ramificación dicotómica, verde purpúreo.

: Simples, alternas, peciolos de 2 $8 \mathrm{~cm}$ de longitud. Ovoides a elipticas u ovado-romboidales, acuminadas, asimétricas, oscuro, envés más claro. De 5-20 $\mathrm{cm}$ de largo por 2-10 $\mathrm{cm}$ de ancho.

Inflorescencia : Flores solitarias, pedúnculo de 3 $6 \mathrm{~mm}$ de longitud, axilares, ubicadas en la bifurcación del tallo.

Flores dentadas, penninervias. Haz verde
Androceo

Gineceo

Fruto

Semillas

\section{Nicandra physaloldes L. Gaertn}

Nombre vulgar : Anrreshuailla, belladona del país, capulí, capuli cimarrón, ccarapa, macman, javuto, orzila de pellejo, taccoro.

Origen : : Perú.

Planta

Tallos

Hojas

Inflorescencia : Flores solitarias, axilares o

Flores

Androceo

Estambres 5, inclusos, epicorolinos. Anteras lineales (dehiscencia longitudinal).

Estigma bilobado, estilo filiforme, ovario súpero bicarpelar.

Cápsula ovoide espinosa de 3-5 cms. de largo por 1.5 a $2.5 \mathrm{cms}$. de ancho con dos logias bipartidas. Se abre por el ápice por medio de 4 valvas.

Numerosas, reniformes de color negro, de 3.5 -4 mm de longitud.

Herbácea, glabra, erecta de 0.30 $80 \mathrm{~cm}$ de altura.

: Cilíndrico, grueso, glabro, ramificado.

: Simples, alternas, glabras, de 2 - $7 \mathrm{~cm}$ de longitud por $1.5 \mathrm{~cm}$ de ancho, ovoides u oblongas, acuminadas, alternadas, sinuadodentadas, penninervias. terminales.

: Hermafroditas, actinomorfas, pediceladas.

Cáliz : Sépalos 5 , envuelve al fruto en forma de vejiga membranoso reticulada.

Corola : Acampanada, pétalos 5, azules o violáceos, blancos en su interior.

: Estambres 5, epipétalos. angulado - lobulado que se rompe circularmente después de la floración. Sépalos 5.

Corola: Infundibiliforme, pétalos 5, blancos 0 violáceos 0 purpurescentes. Mide $7-8 \mathrm{~cm}$ de longitud.

Cáliz : Tubular de $3 \mathrm{~cm}$ de largo, 
Gineceo

: Estigma cónico-globoso, estilo cilíndrico, filoso, ovario súpero 35 locular, multiovulado bicarpelar.

Fruto

: Baya, esférica, multiseminado, envuelta por el cáliz acrescente de 0.5 - $1 \mathrm{~cm}$ de diámetro.

Semillas : Numerosas, reniformes, glabras, amarillo - parduzcas, de $1 \mathrm{~mm}$ de longitud.

Propagación : Por semillas.

\section{Nicotiana glauca graham}

Nombre vulgar : Falso tabaco, tabaquillo, ccajamachu, caja mata, supai ccarcco, palam - palam.

Origen : Argentina.

Planta

Hojas

Inflorescencia : Panículas cortas glabras o

Flores

Androceo

Gineceo

Fruto pubescentes, terminales con numerosas flores.

Arbusto o subarbusto hasta $4 \mathrm{~m}$ de altura muy ramificada. Ramas ascendentes y ligeramente decumbentes, glabras y glaucas.

Simples, alternas, de color glauco, eliptica o lanceolada, aovada lanceoladas, glabras de $0.5-2.5$ $\mathrm{dm}$ de longitud, agudas, base, borde entero, penninervias.

Hermafroditas, actinomorfas o más o menos zigomorfas, pediceladas, pedicelos de $3-5$ $\mathrm{mm}$ de longitud.

Cáliz : Tubuloso-acampanado, 5 lóbulos agudos, persistente.

Corola : Tubulosa. Gamopétala, pétalos 5, amarillo - verdosos, pubescentes.

: Estambres 5, incluidos epicorolinos. Anteras con dehiscencia longitudinal.

: Estigma capitado, estilo filiforme, ovario súpero, bicarpelar, bilocular, multiovulado.

: cápsula de 7-15 mm de largo, membranosa, dehiscente por 2-4 valvas, multiseminadas.
Semillas

Propagación : Por semillas

\section{FAMILIA PLANTAGINACEAE}

Plantago lanceolata $\mathrm{L}$.

Nombre vulgar : Llantén, llantén hembra, platén, siete venas.

Origen

Europa, norte de Asia.

Planta

Raiz

Hojas

Inflorescencia

Flores

Androceo

Gineceo

Acaule, de $10-40 \mathrm{~cm}$.

Pivotante, gemifera, corta, gruesa.

Arrosetadas, simples, estrechas, lanceoladas u oblongoanceoladas, glabras o glabrescentes, ápice acuminado, margen entero, con 3-5 nervaduras paralelas.

Limbo de 15 - $30 \mathrm{~cm}$ largo por 1 $2.5 \mathrm{~cm}$ de ancho, peciolo acanalado. Eje floral erecto, delgado de $30-60 \mathrm{~cm}$ de altura.

: En espiga terminal corta, aovada y aovada cónica, finalmente cilíndrica, densa de $2.5-10 \mathrm{~cm}$ de largo por 8-12 mm de diámetro.

: Inconspicuas hermafroditas, actinomorfas, tetrámeras, Anemógamas.

Cáliz: Con 4 sépalos breves persistentes, papiráceos, color marrón.

Corola : Con 4 pétalos pequeños marrón-blanquecinos.

: Con cuatro estambres unidos al tubo de la corola y más largos que ella, blancos, filamentos largos y sutiles. Anteras prominentes móviles. Polen suelto y ligero.

: Bicarpelar, carpelos soldados en un ovario bilocular.

Fruto

: Cápsula oblonga, obtusa, de pericarpio papiráceo, deshiscente transversalmente, biseminada.

Semillas
: Estrechas naviculares de color moreno claro a oscuro, de 1.5 - 


\section{$2.5 \mathrm{~cm}$ de largo.}

Propagación : Por semillas. Por segmentos de las raíces.

\section{Plantago major L.}

Nombre vulgar : Llantén macho, Ilantai, Ilantén, torraja cimarrona.

\begin{tabular}{|c|c|}
\hline Origen & : Europa, Asia menor. \\
\hline Planta & $\begin{array}{l}\text { Perenne acaule hasta } 0.40 \mathrm{~m} \text { de } \\
\text { altura. }\end{array}$ \\
\hline Raíz & : Pivotante, corta y gemífera. \\
\hline \multirow[t]{2}{*}{ Hojas } & $\begin{array}{l}\text { Arrosetadas, simples, largamente } \\
\text { pecioladas. El peciolo de } 3-12 \\
\mathrm{~cm} \text { de largo es grueso, acanalado. }\end{array}$ \\
\hline & $\begin{array}{l}\text { Escapo floral erecto, cilindrico de } \\
15-40 \mathrm{~cm} \text { de altura, gruesas, } \\
\text { semicoriáceas, anchas, ovado, } \\
\text { elípticas, agudas o subagudas en } \\
\text { el ápice, sinuadas o irregularmente } \\
\text { dentadas en el margen. } \\
\text { Nervaduras paralelas en número } \\
\text { de } 5-7 \text {. }\end{array}$ \\
\hline
\end{tabular}

Lámina de $6-15 \mathrm{~cm}$ de largo y hasta $12 \mathrm{~cm}$ de ancho.

Inflorescencia : En espiga terminal cilindrica densa alargada de más de $5 \mathrm{~mm}$. de ancho y más de $10 \mathrm{cms}$. de largo.

Flores

: Pequeñas, hermafroditas,
actinomorfas.

Cáliz: Herbáceo, con 4 sépalos membranáceos, elipticos.

Corola: Cupuliforme, con 4 pétalos retorcidos en la punta.

Androceo : Cuatro estambres, insertos en la base del tubo de la corola. Anteras elípticas.
Gineceo
: Estilo filiforme. Estigma piloso papiloso. Ovario súpero bicarpelar, bilocular.
Fruto
Semillas
: Cápsula ovoide, con dehiscencia transversal multisemilladas (6-30).
Propagación

\section{FAMILIA COMPOSITAE (ASTERAESEAS)}

\section{Erigeron bonariensis $L$.}

Nombre vulgar : Kiuña.

Origen

: Sudamérica (Argentina).

Planta

: Anual, verde grisácea, de $30-0.80$ $\mathrm{cm}$ de altura.

Tallos

Hojas

Estriados, hojosos hasta el ápice.

: Dimorfismo foliar. Hojas superiores lineales, enteras, agudas, densamente pubescentes, de $2-5 \mathrm{~cm}$ de longitud. Hojas inferiores oblanceoladas, lobadas o rara vez enteras, tamaño variable.

Inflorescencia : Capitulo dispuesto en panoja contraída que por alargamiento de los ejes y pedícelos se transforma en un pseudo-corimbo. Involucro hemisférico, con brácteas lineales.

Flores

: Dimorfas blancas, las marginales femeninas filiformes. Las flores del disco hermafroditas, tubulosas.

Fruto : Aquenio oblongo, comprimido con pappus blanco o rosado.

Propagación : Por semillas. Diseminación anemófila.

\section{Eclipta alba (L.) Hassk}

Nombre vulgar : Botón blanco, botoncillo, naparo cimarrón.

Origen : América.

Planta

Herbácea, erguida laxamente pubescente. Mide de 15 a $80 \mathrm{~cm}$ de altura.

Tallo

Erguido, cilindrico, ramificado, verde, ramas ascendentes estrigosas.

Hojas

: Simples, opuestas, sésiles, lanceoladas, agudas u obtusas, atenuadas, enteras o aserradodentadas, penninervias, haz pubescente. Lámina foliar 2-10 $\mathrm{cms}$. de largo por $0.5-2.5 \mathrm{~cm}$ de ancho.

Inflorescencia : Capítulos pequeños numerosos, 
cimosos, en el ápice de las ramitas y en las axilas de las hojas superiores, largamente pedunculados. Involucro acampanado o hemisférico, brácteas semibiseriadas, herbáceas.

Flores

Fruto

Propagación : Por semillas.

\section{Galinsoga parviflora Cav.}

Nombre vulgar

Pacayuyo, pacpa yuyo, albahaca silvestre, saetilla.

$\begin{array}{ll}\text { Origen } & : \text { Sudamérica (Eur) } . \\ \text { Planta } & \text { : Anual de } 0.20-0.80 \mathrm{~cm} \text { de altura. } \\ \text { Tallos } & \text { : Delgados, erguidos, casi glabro, } \\ & \text { ramificados, pubescentes. }\end{array}$

Hojas : Simples, opuestas, pecioladas, de $2.5 \mathrm{~cm}$ de largo, ápice agudo, base redondeada, borde crenadoaserrado, 3 nervadas desde la base. Hojas inferiores pecioladas, las superiores sésiles o casi.

Inflorescencia : Capítulos heterógamos pequeños, numerosos de $6 \mathrm{~mm}$ de diámetro, largamente pedunculados, dispuestos en cimas paucifloras que nacen de las axilas de las hojas superiores de $2.5-3 \mathrm{~mm}$ de altura.

Involucro acampanado, formado por brácteas imbricadas.

Flores

\section{: Dimorfas.}

Flores periféricas: 4-5 liguladas, femeninas trimarginales dentadas en el ápice, blancas.
Flores del disco: Tubulares, hermafroditas, amarillas.

Fruto

Aquenio turbinado - obovado, pubescente.

Propagación : Mediante semillas.

Heterosperma diversifolia H.B.K.

Nombre vulgar : Saetilla.

Origen

: América.

Planta

Tallo

Hojas

Inflorescencia

Flores

Fruto

: Anual, hasta $30-50 \mathrm{~cm}$ de altura.

: Ramificado.

Simples opuestas, sésiles, cuneadas, glabras.

Inferiores: Trilobadas.

Superiores:Simples, de base atenuada sobre el peciolo, dentadas en la mitad superior.

: Capítulos pequeños, heterógamos, largamente pedunculados terminales o axilares. Pedúnculos de $1.5-4 \mathrm{~cm}$ de longitud.

Involucro acampanado o cilindrico. Brácteas biseriadas

: Dimorfas.

Flores periféricas: $\mathrm{F}$ e me ninas. Lígulas pequeñas, amarillas 3 dentadas en el ápice.

Flores del disco: Hermafroditas, tubulosas amarillas, 5 partidas en el limbo.

Aquenio obovado, comprimido glabro. Con 2 tipos de aquenios.

De las flores periféricas son múticos y alados en los bordes y los de las flores centrales 2 aristados.

Propagación : Por semillas.

\section{Senecio vulgaris $\mathrm{L}$.}

Nombre vulgar : Hierba cana, cineraria.

Origen

: Cosmopolita.

Planta

: Anual, erguida de $10-40 \mathrm{~cm}$ de altura, glabra o lanuginosa, especialmente en las axilas de las hojas superiores. 
Tallo

Hojas

Inflorescencia

Flores

Fruto

Propagación

\section{Taraxacum officiniale Weber on Wiggers}

Nombre vulgar

Planta

Hojas

Inflorescencia

Flores diente de león, amargón, lechuguilla, radicha, radicheta.

: Cilindrico, pubescente.

: Inferiores: Alternas, obovales, inciso-dentada o inciso-lobada, pubescentes en envés, peciolo alado.

Superiores: Pinnatipartidas o divididas, sésiles, semiabrazadoras de $2-8 \mathrm{~cm}$. de longitud por $0.5-2.5 \mathrm{~cm}$ de ancho.

pedunculados, aislados o agrupados en comprimidos o falsas umbelas, brevemente pedicelados. Involucro cilindrico, caliculado. Brácteas lineales. receptáculo plano sin cerdas.

: Hermafrodita con corona tubular.

Periféricas: Liguladas amarillas tubulares.

Centrales: tubulosas amarillas.

: Aquenio casi cilindrico.

Por semillas.

:Perenne latífera, hemicriptófita y acaule.

: Simples radicales arrosetadas enteras. Oblongas, obovales, espatuladas, dentadas y más o menos profundamente runcinadas, pinnatifidas, glabras, tamaño variable, según el medio donde habita la planta.
Capítulos
homógamos relativamente grandes, sobre escapos huecos, desnudos, largamente pedunculados. Involucro acampanado, brácteas involucrales lineales numerosas, 3 seriadas.

Numerosas isomorfas, centrales y periféricas hermafroditas, liguladas, 5 dentadas en el ápice, de color amarillo. Las lígulas comúnmente con una línea parda en el envés.

Fruto

: Aquenio fusiforme anguloso tuberculado en la parte superior, prolongado en el ápice en un largo pico que soporta en su extremo el vilano formado por numerosos pelos sencillos. Aquenio de 3.5-4 milimetros de largo.

Propagación : Por semillas.

\section{Xanthium spinosum $L$.}

Nombre vulgar : Cepa caballo, abrojo chico, abrojillo, allcco-quisca, alcco quisca, espina de perro, Juan Alonso, Hierba de Alonso, Hierba de Juan Alonso.

Origen : Cosmopolita.

Planta

: Herbácea, espinosa, monoica de $0.25-0.50 \mathrm{~m}$ de altura.

Tallos

Erguidos, ramificados, glabros o tenuemente lanuginoso, con espinas amarillas trifidas de $2 \mathrm{~cm}$ de longitud, situada junto a la base de las hojas.

Hojas : Simples alternas, cortamente pecioladas, lanceoladas, agudas, atenuadas, enteras o con uno o dos lóbulos a cada lado del borde, de 2.5 - $4 \mathrm{~cm}$ de largo por $0.5-1$ $\mathrm{cm}$ de ancho.

Haz poco pubescente, envés blanco - tormentoso.

Inflorescencia : Capitulos pequeños unisexuales.

Capitulos masculinos, en espigas terminales laxas, globosos de 3$4.5 \mathrm{~mm}$ de diámetro.

Capítulos femeninos, axilares. Involucro cubierto por gloquidios ganchudos de unos $2 \mathrm{~mm}$.

Fruto

: Aquenio, con picos del fruto, espinosos divergentes rectos, unos más que otros de $1 \mathrm{~cm}$ de longitud.

Propagación : Por semillas. La diseminación se efectúa por los animales, como por el hombre, debido a los involucros fructíferos del fruto. 
FIGURA N ${ }^{\circ}$ 1: Pennisetum clandestinum Hochst. 'Kikuyo'

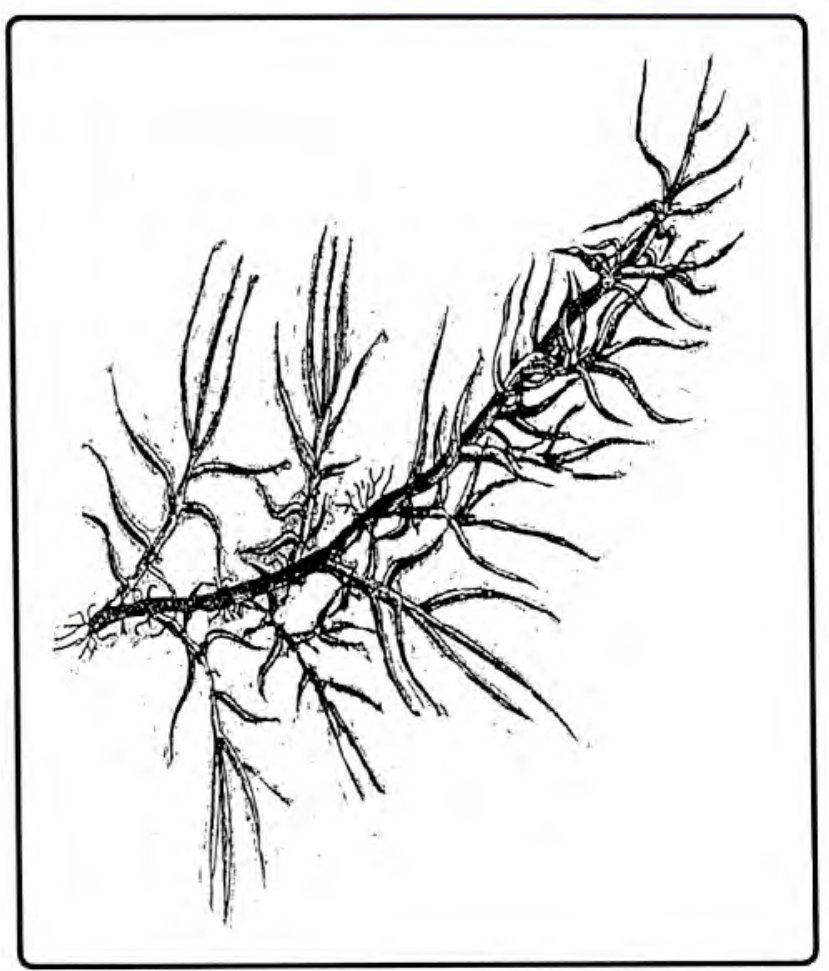

FIGURA N ${ }^{\circ}$ 2: Setaria verticillata (1.) Beauv. 'Cola de zorro'

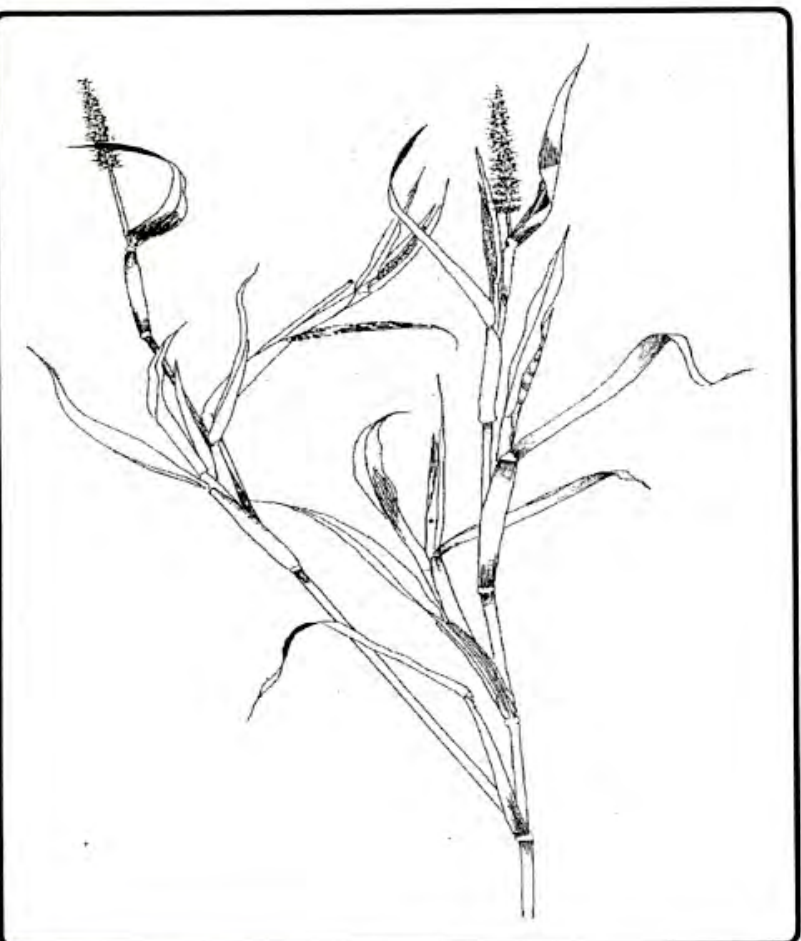

FIGURA N ${ }^{\circ}$ 3: Nothoscordium inodorum (Ait). Nicholson. 'Cebollino'

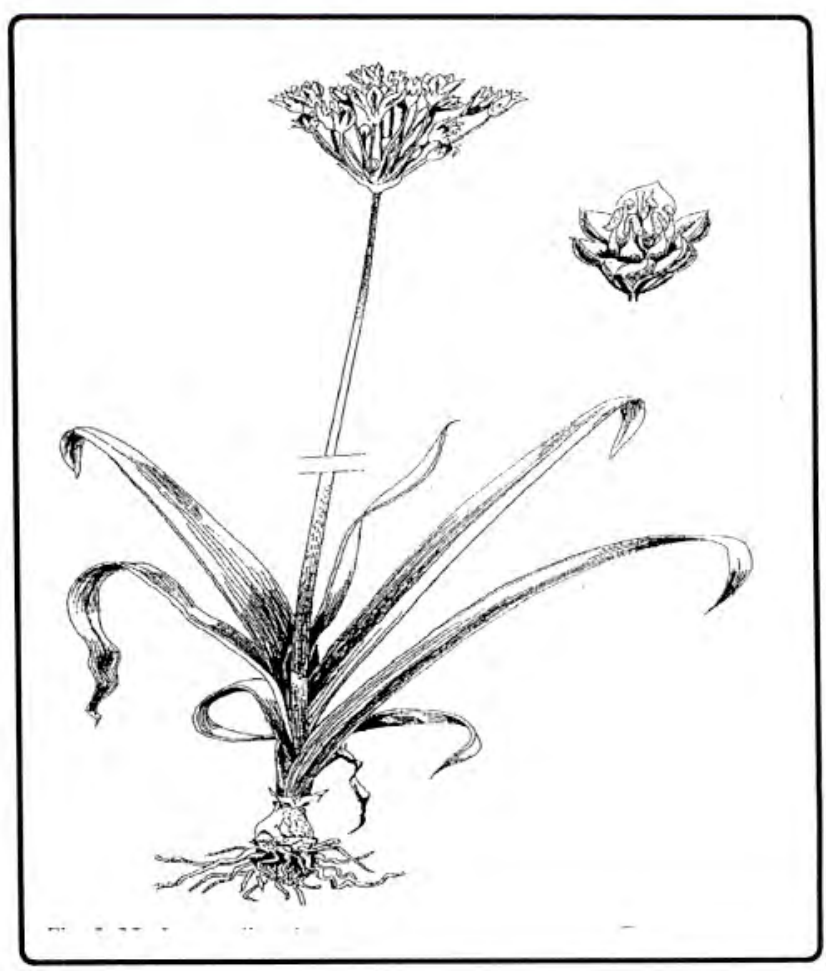

FIGURA N ${ }^{\circ}$ 4: Chenopodium album L. 'Quinua silvestre'

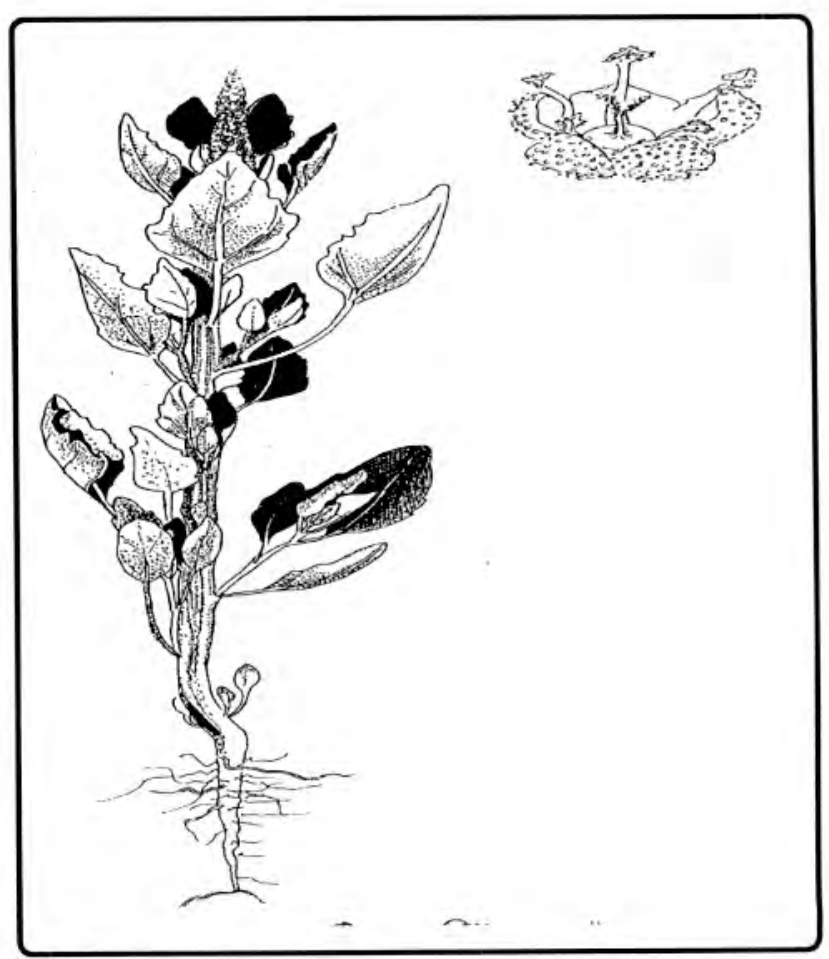


FIGURA N ${ }^{\circ}$ 5: Argemone subfusiformis Ownb. 'Cardo santo'

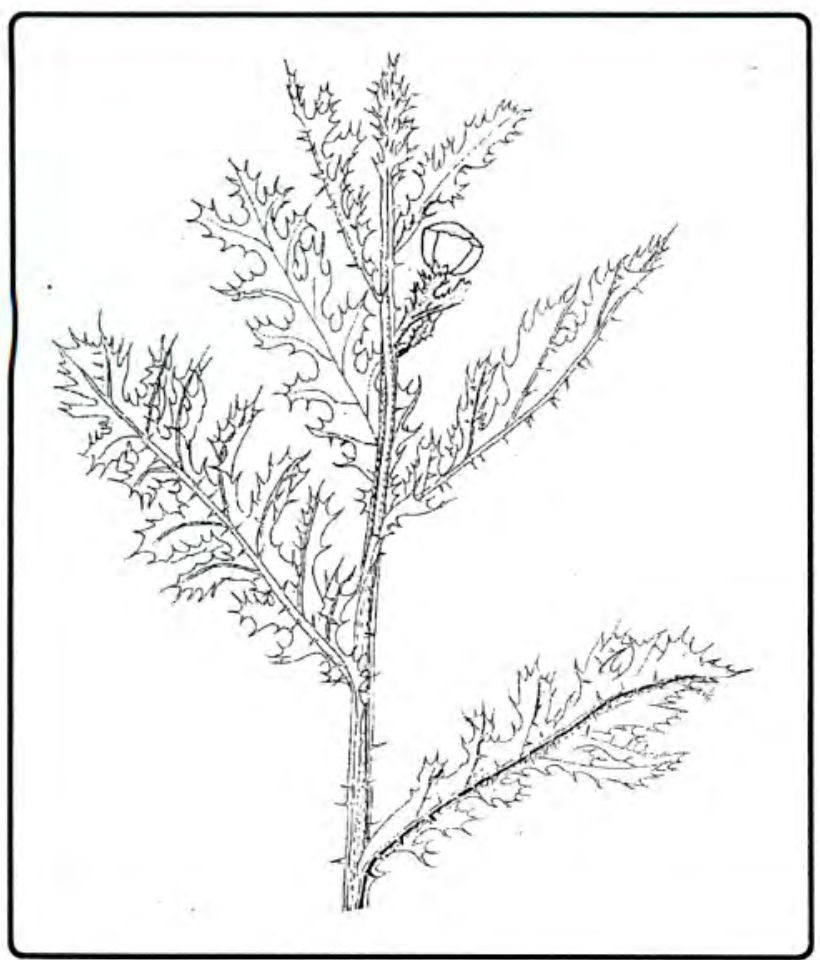

FIGURA N ${ }^{\circ}$ 6: Fumaria capreolata L. 'Perejilillo'

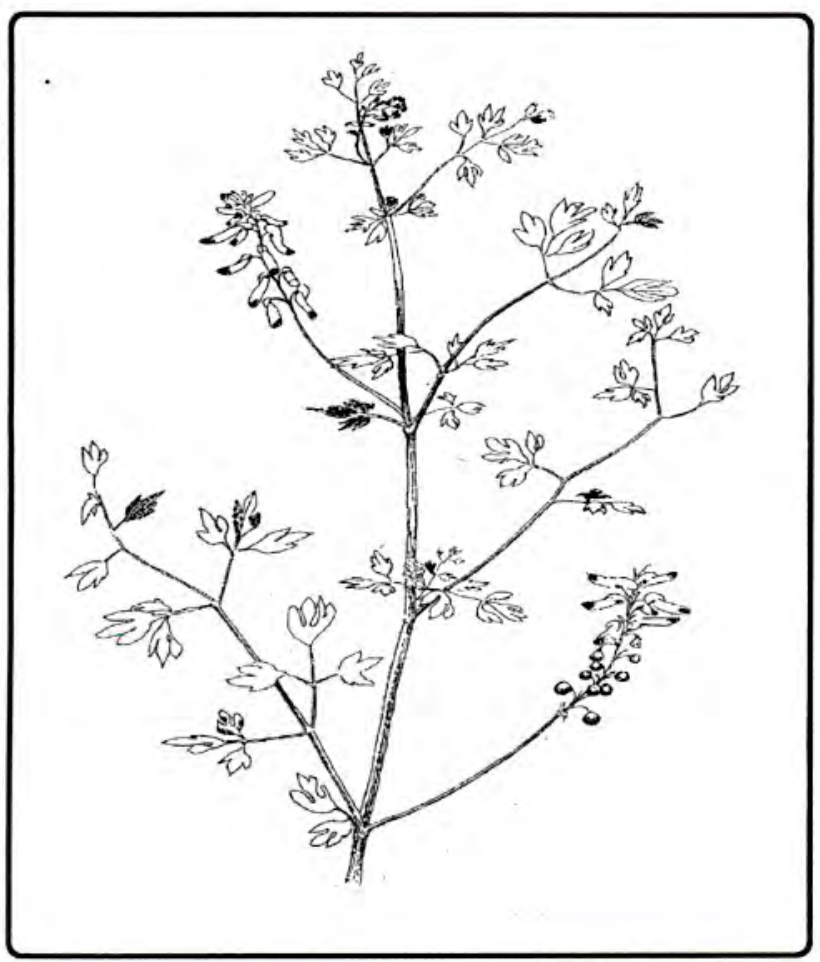

FIGURA N ${ }^{\circ} 7$ : Medicago polimorpha L. 'Trébol'

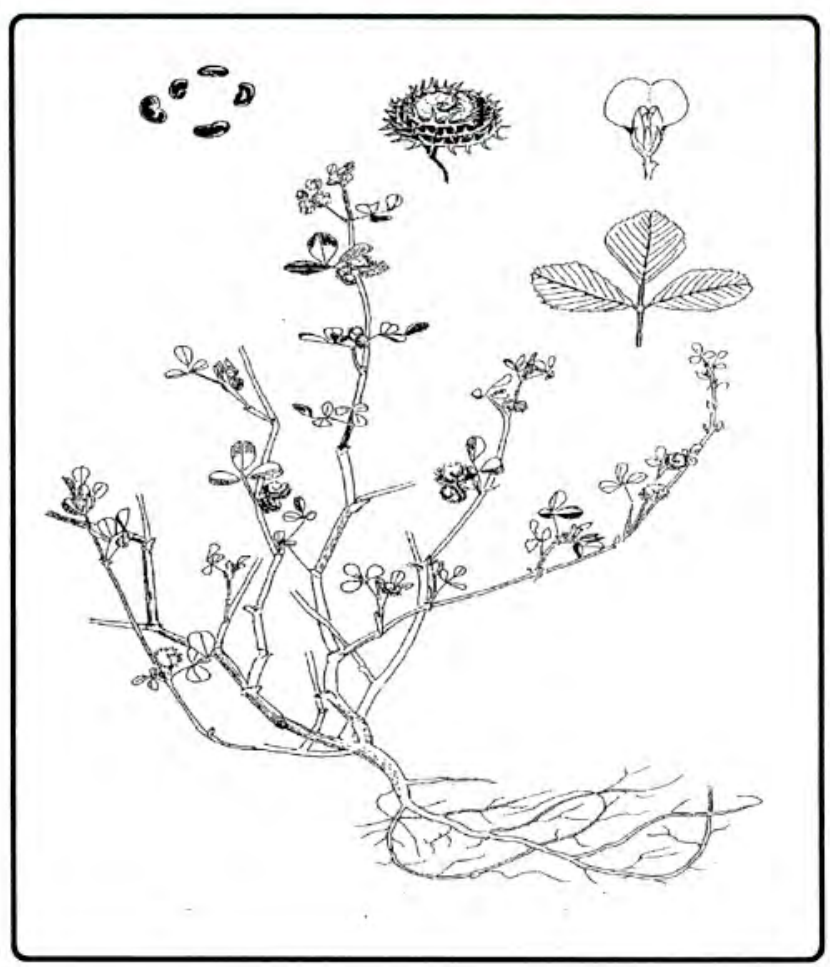

FIGURA N ${ }^{\circ}$ 8: Vicia graminea Smith. 'Arvejilla'

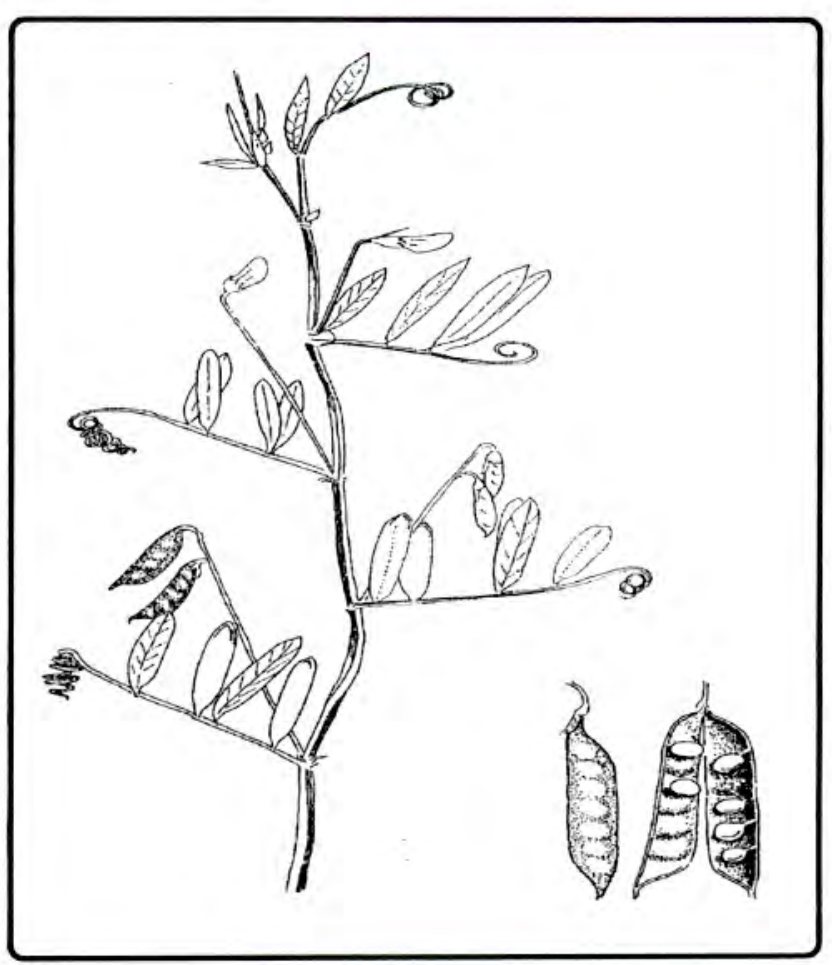


FIGURA Nº 9: Oxalis cernua Thumberg. 'Vinagrillo'

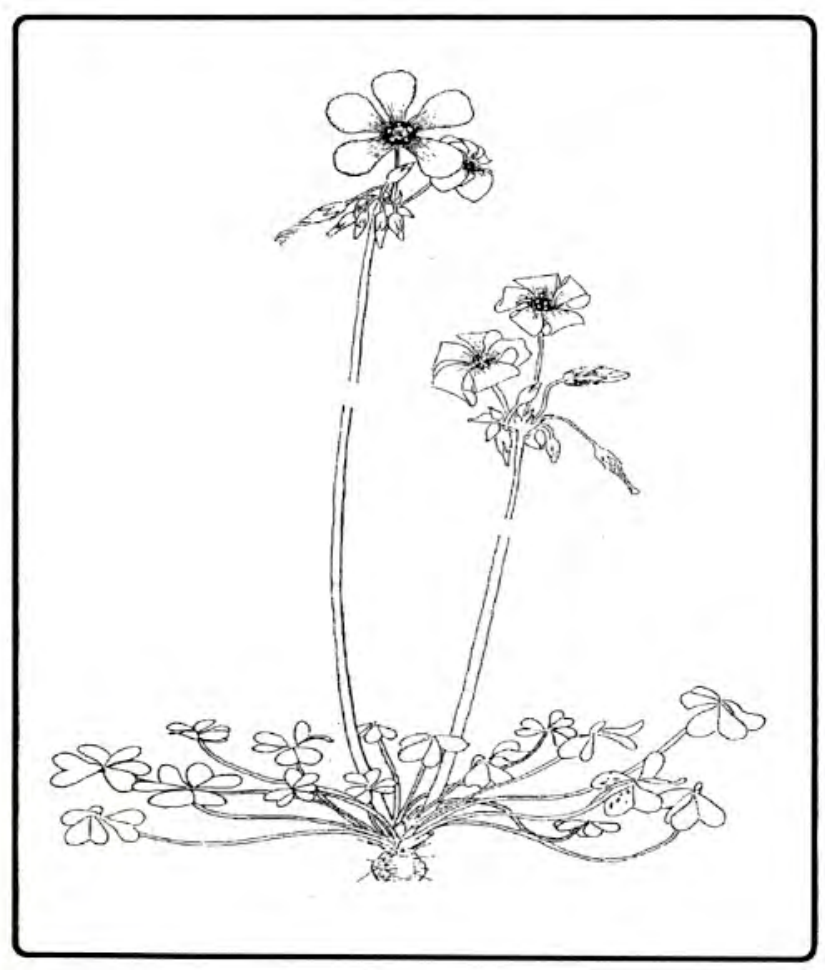

FIGURA N ${ }^{\circ}$ 10: Oxalis corniculata L. 'Falso trébol'

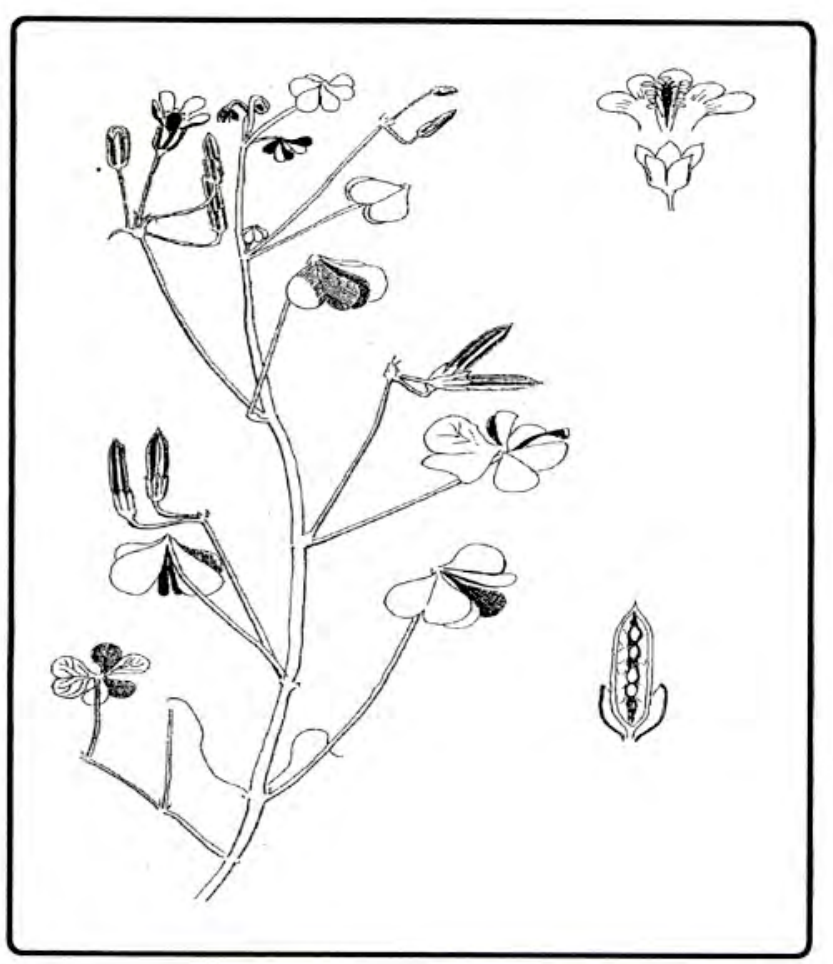

FIGURA N ${ }^{\circ}$ 11: Euphorbia hirta L. 'Lechera'

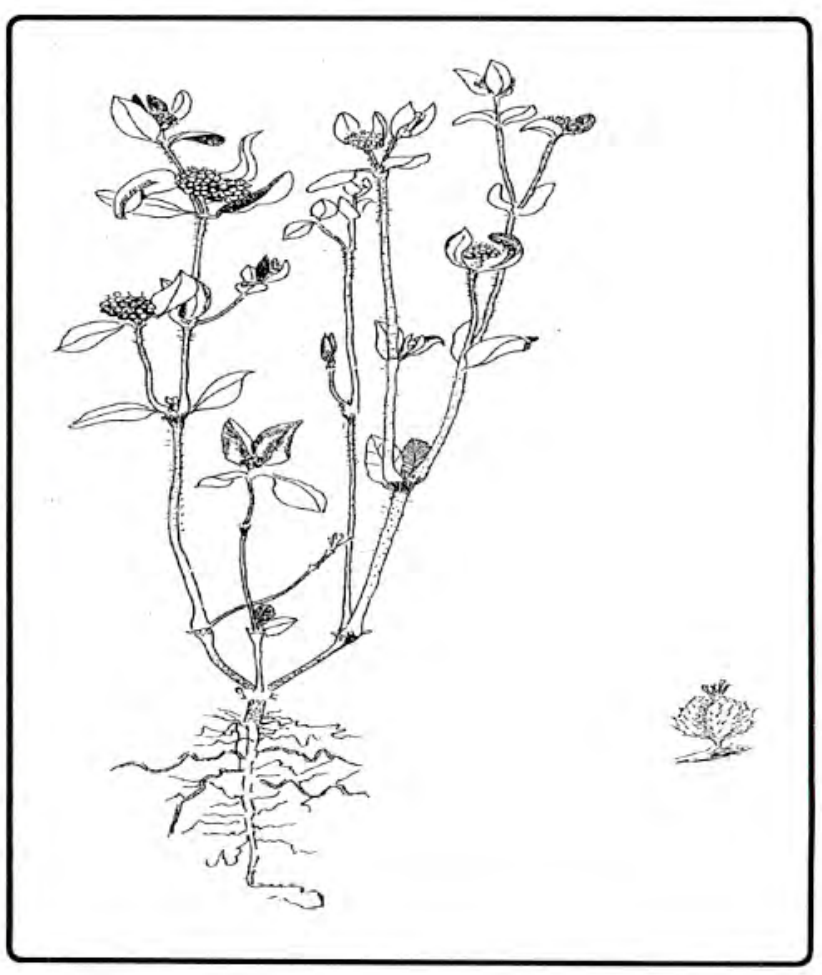

FIGURA No 12: Euphorbia peplus L. 'Lechera'

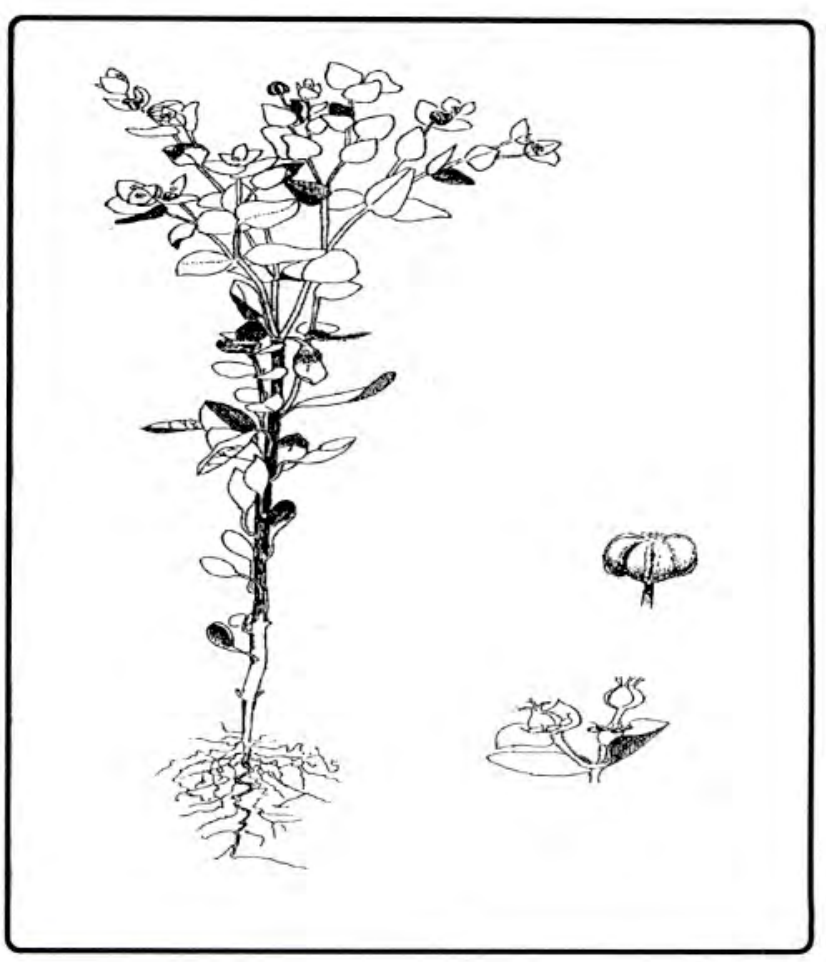


FIGURA N ${ }^{\circ}$ 13: Abutilon teophastri Garke \& Schum. 'Farolito chino'

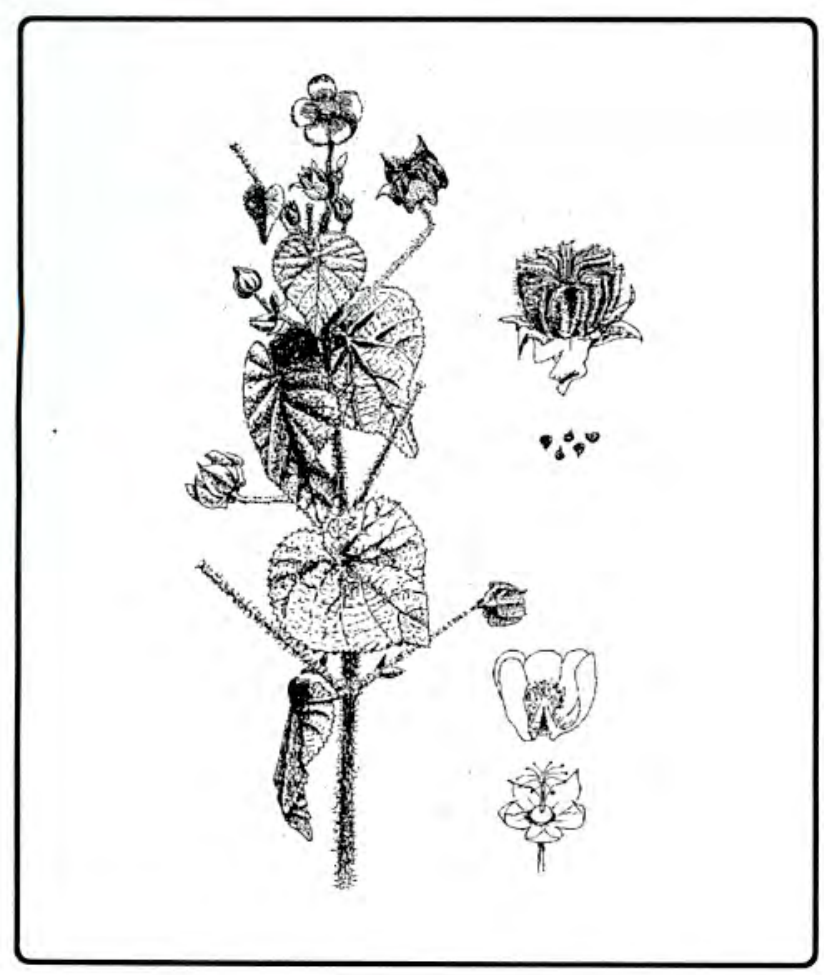

FIGURA N ${ }^{\circ}$ 14: Anagallis arvensis L. 'Pimpinela escarlata'

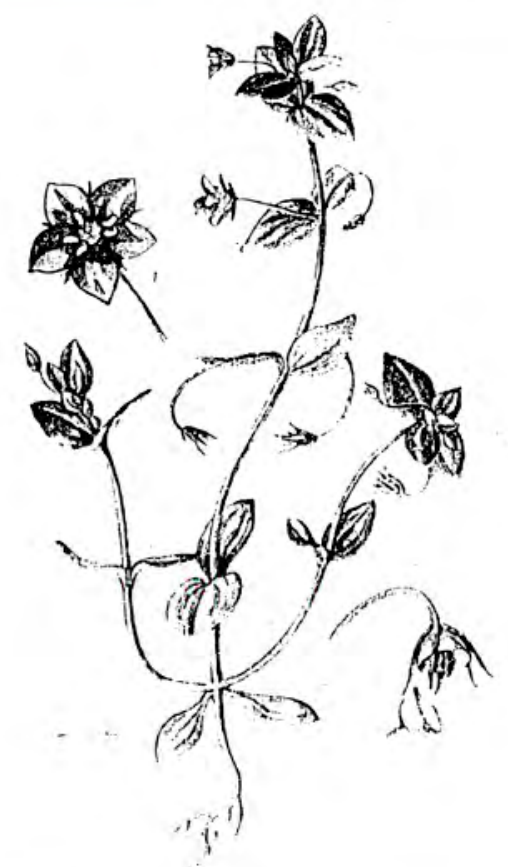

FIGURA N ${ }^{\circ}$ 15: Asclepias curassavica L. 'Flor de muerto'

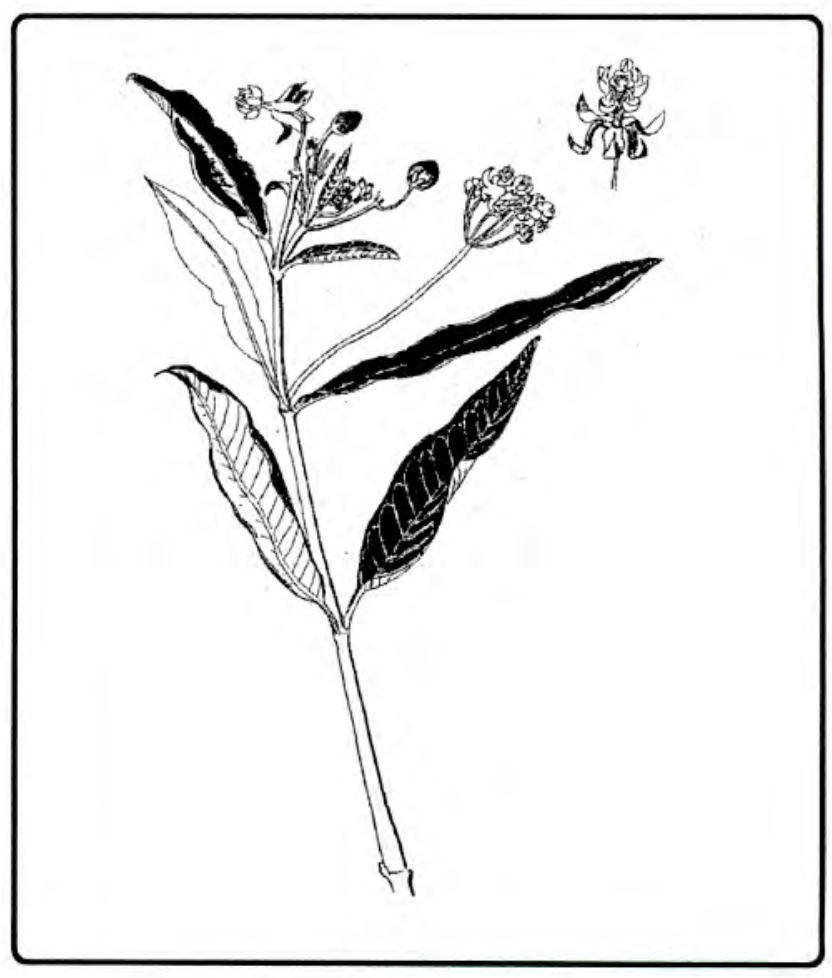

FIGURA № 16: Ipomoea purpurea (L.) Roth. 'Campanilla'

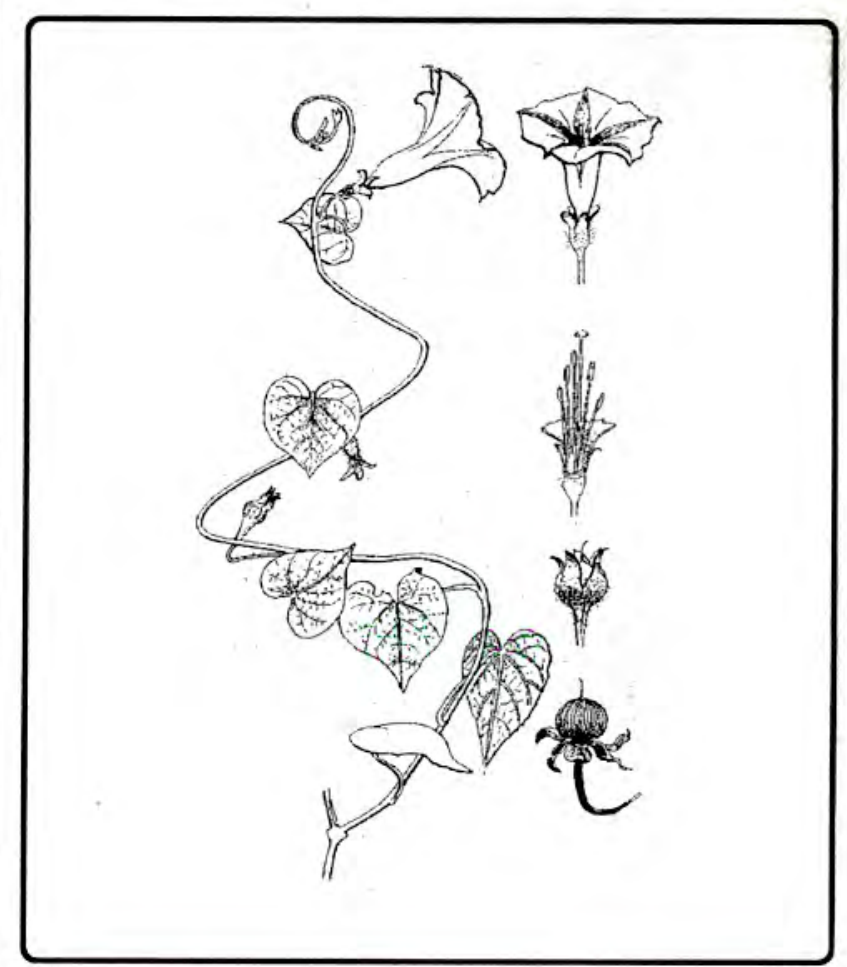


FIGURA № 17: Datura stramonium L. 'Chamico'

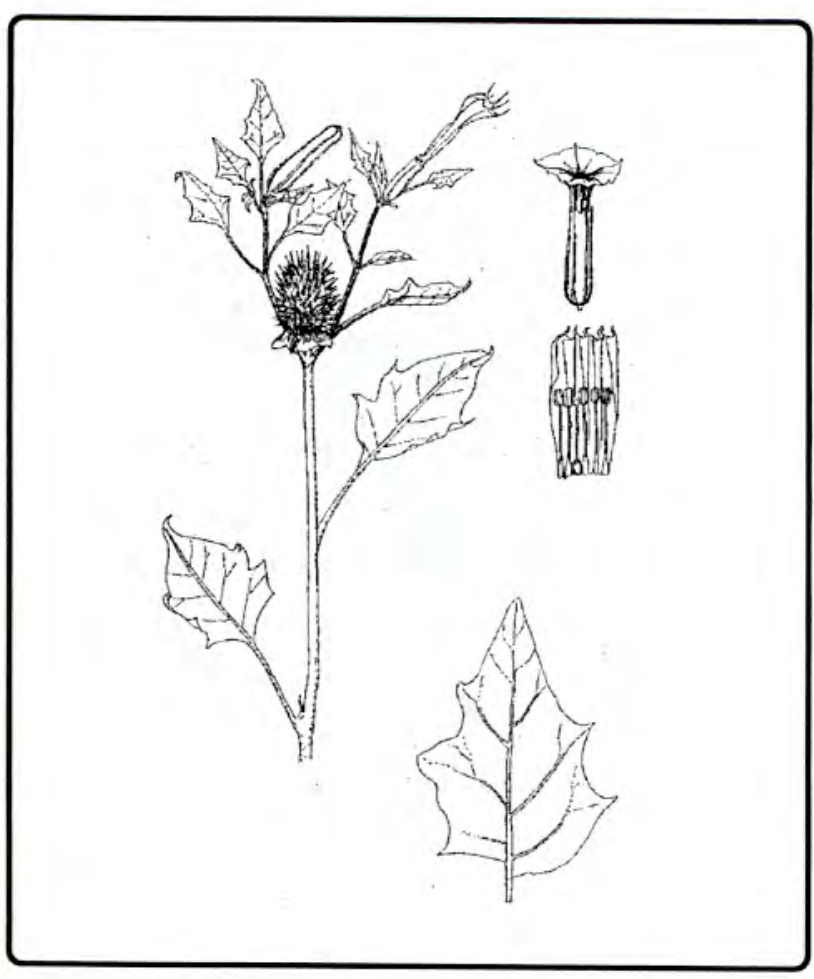

FIGURA No 18: Plantago major L. 'Llantén macho'

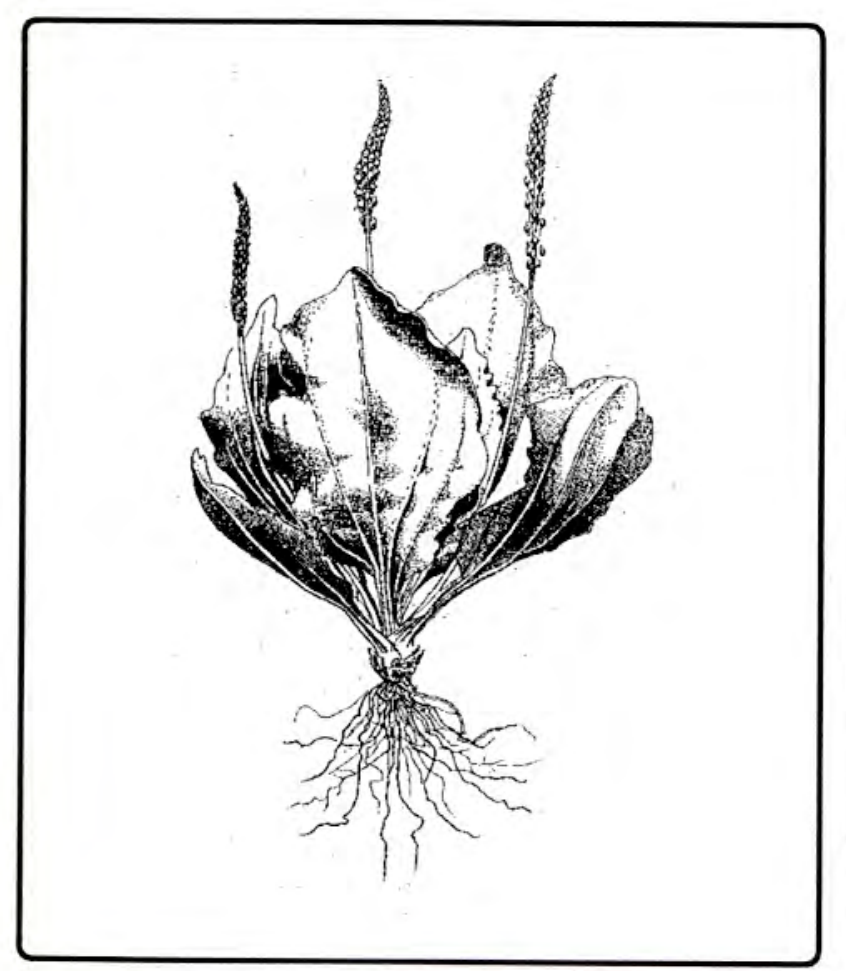

FIGURA № 19: Erigeron bonariensis L. 'Kiuña'

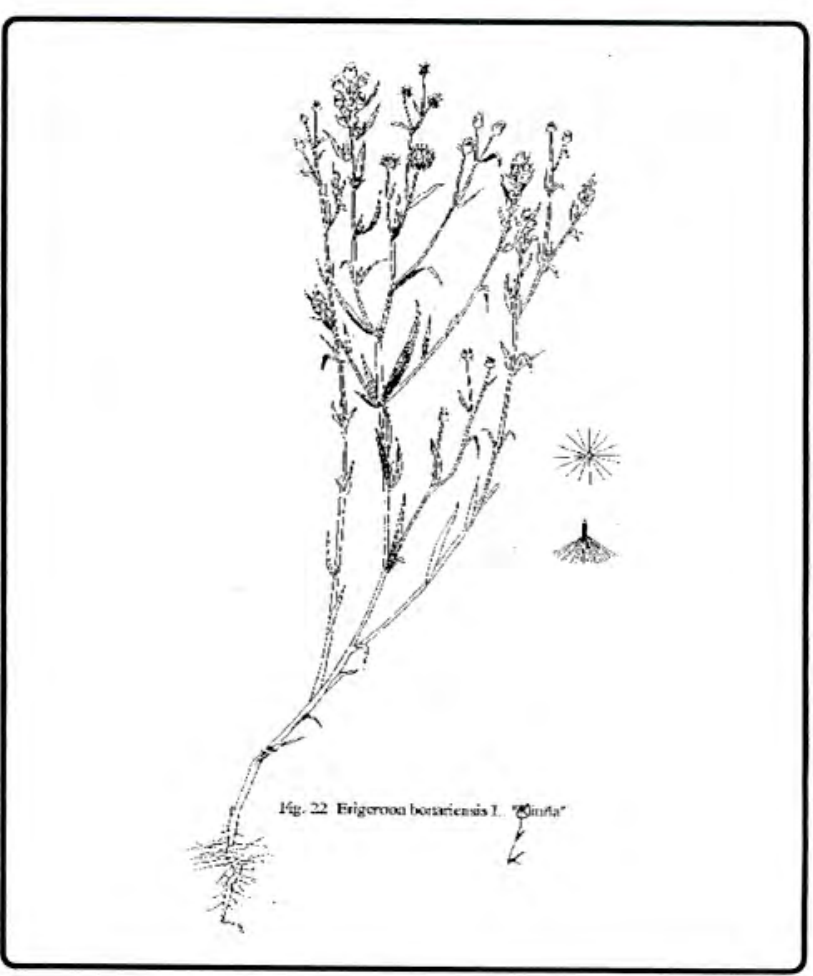

FIGURA No 20: Galinsoga parviflora Cav. 'Pacayuyo'

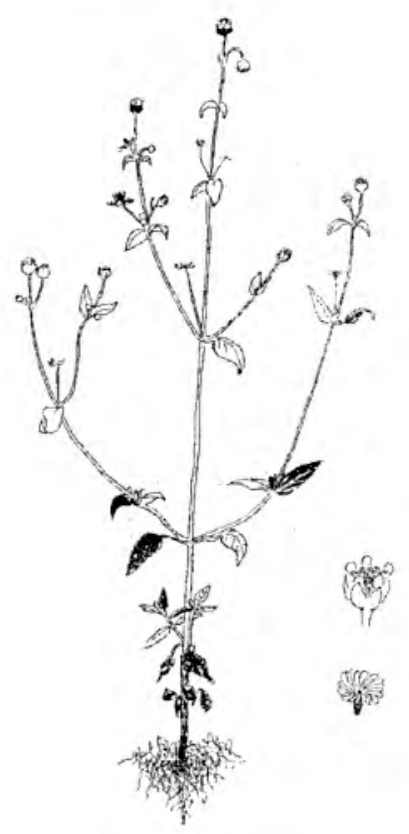


FIGURA N ${ }^{\circ}$ 21: Heterosperma diversifolia H.B.K.

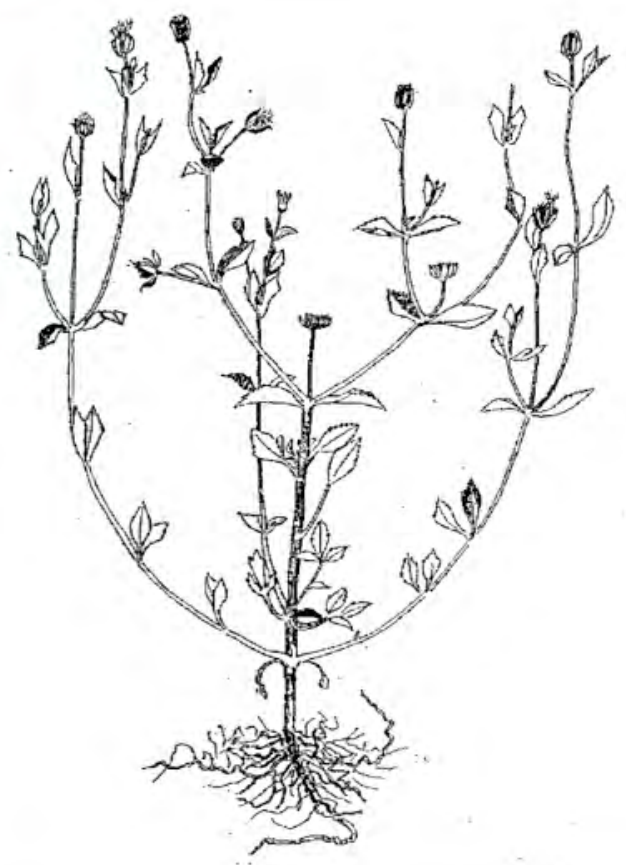

FIGURA $N^{\circ}$ 22: Taraxacum officinale Weber. 'Diente de león'

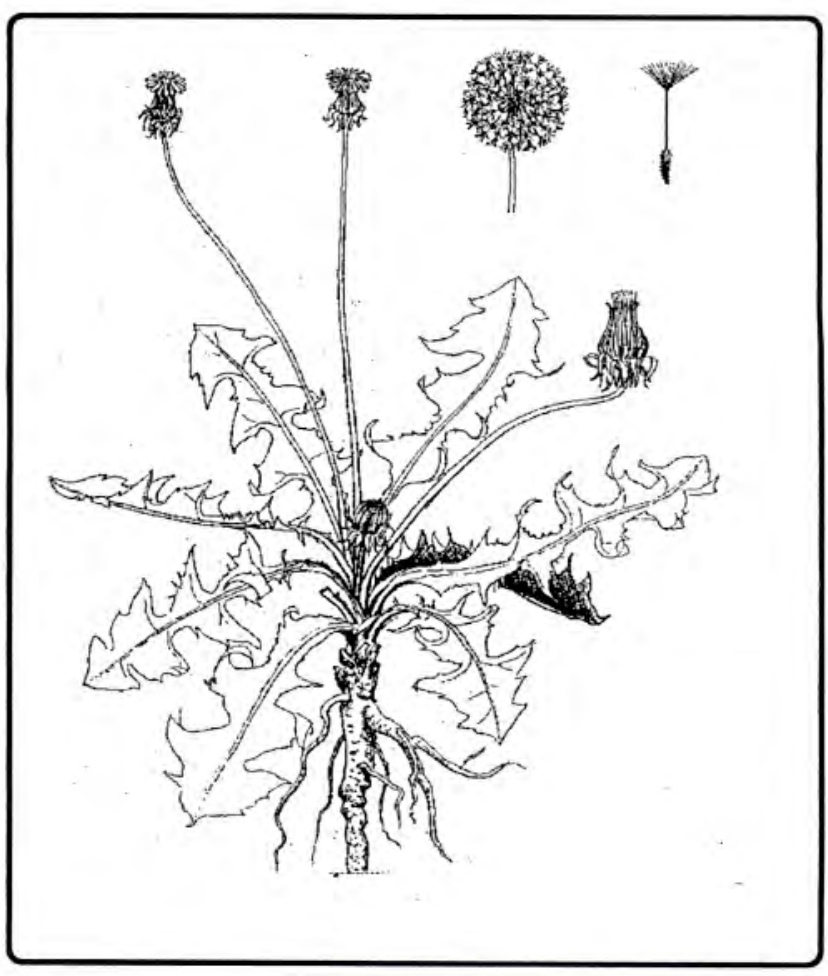

\section{BIBLIOGRAFIA}

FERREYRA, R. (1970). Flora Invasora de los Cultivos de Pucallpa y Tingo María. Lima Perú.

GUERRA, C.; ZEGARRA, R.; DEZA, E. (1995). Estudio Preliminar de los Afidos (Homoptera - Aphididae) de Importancia Agricola del Valle de Tacna. Revista Ciencia y Desarrollo $N^{\circ} 1$. UNJBG. Tacna-Perú.

HELFGOTT, S. Control de Malezas. Biblioteca Agropecuaria del Perú.

SAGÁSTEGUI, A. (1973). Manual de las Malezas de la Costa Nor-Peruana.

VILLARIAS, J.L. (1979). Atlas de Malas Hierbas. Ed. Mundi Prensa. Madrid-España.
ZEGARRA, R. (1992). Estudio Biosistemático y Posibilidades de Control de las Malezas Halófitas de Tacna y Moquegua. Revista Nueva Imagen. UNJBG-TacnaPerú.

ZEGARRA, R. (1992). Vegetación Desértica de las Lomas de Tacna. Estudio Biosistemático y Potencial Forrajero. Revista Nueva Imagen. UNJBG. TacnaPerú.

ZEGARRA, R. (1994). Vegetación Desértica Perenne del Departamento de Tacna, Estudio Biosistemático y Ecológico. Revista Nueva Imagen. UNJBG. TacnaPerú.

ZEGARRA, R. (1995). Plantas Ornamentales de la Ciudad de Tacna. Revista Ciencia \& Desarrollo. UNJBG. TacnaPerú. 